\title{
Effect of Personal Characteristics on Social Accounting Initiatives: Evidence from Pakistan
}

\author{
Muhammad Shaharyar Saeed \\ Research Scholar \\ Karachi University Business School, University of Karachi, Pakistan \\ E-mail: muhammadshaharyar95@gmail.com \\ Dr Danish Ahmed Siddiqui \\ Associate Professor \\ Karachi University Business School, University of Karachi, Pakistan \\ E-mail: daanish79@hotmail.com
}

Received: October 9, 2021 Accepted: November 9, 2021 Published: November 10, 2021

doi:10.5296/ijmis.v6i1.19173 URL: https://doi.org/10.5296/ijmis.v6i1.19173

\begin{abstract}
The research works with two separate but closely connected themes of individual employee behaviour and organisation-wide initiatives that are further broken down into two dimensions of Social Entrepreneurship Profile and Social Accounting (SA). This research study seeks to identify the social entrepreneurship profile that highlights the specific personal characteristics of employees working in an organisation; secondly, it attempts to understand how the broader initiatives that help today's organisations become more socially responsible. Factors covered in Personal Characteristics included 1. Sociality, 2. Innovativeness, 3. Market-orientation, and 4. The ability of Identifying New Opportunities (INO). Social Accounting Initiatives included Internal Attitude (IA), and Subjective norms (SN), each is classified as1.Pragmatic, 2. Moral, and 3. Cognitive, as well as Perceived Behavioural Control (PBC). For this purpose, A survey was conducted of 75 firms, and their decision-makers 306. were surveyed about their characteristics as well as the social accounting initiatives in their firms, usinga close-ended questionnaire. Total of306 decision-makers was surveyedabout four employees per organisation. Dataset was analyzed using confirmatory factor analysis and structured equation modelling. The results suggested that innovativenessand INO seem to have a positive and significant impact on pragmatic and moralIA. As well as moral SN. Similarly, sociality and innovativeness positively affecting moral IA. Sociality also seems to be affecting moral IA, pragmatic SN, and PBC, however, it has a negative impact on cognitive
\end{abstract}




\section{Macrothink}

International Journal of Management Innovation Systems

ISSN 1943-1384 2021, Vol. 6, No. 1

SN. Market orientation also has a significant positive impact on cognitive IA and SN. Lastly, INO seems to affect Perceived Behavioural Control. Implications and limitations of the study are discussed.

Keywords: Social Accounting Initiatives, Social Entrepreneurship, Innovation, Employee behaviour, Social Accounting, Market-Orientation 


\section{Macrothink}

\section{Introduction}

\subsection{Background of the Study}

A growing new trend in the discipline of entrepreneurship is social entrepreneurship (Othman $\&$ Wahid, 2014). From the point-of-view of developing human capital in meeting a nation's needs, the qualities of a social entrepreneur must be cultivated and nurtured in managers and employees working in for-profit and not-for-profit organisations alike. The social entrepreneurial characteristics are important for the managerial and non-managerial staff working in different organisations across multiple industries and sectors.

Social entrepreneurs are not like profit-oriented business entrepreneurs, but they are motivated to improve society, become agents of change for society, take advantage of opportunities that others do not realize to improve the system, create new approaches and seek solutions to transform society towards more life well. The souls of social change agents owned by them will be more 'altruist' by focusing on solving community problems innovatively.

The term "social entrepreneurship", which has a real Latin root (Korkmaz, 2000, Y1lmaz, 2014), is originally based on the activities of the French economy in the seventeenth and eighteenth centuries (Dees, 1998). Although the idea of entrepreneurship was originally monetary, today there is enough social dimension (Chell, 2007). Social entrepreneurship is becoming increasingly popular around the world and is taught in numerous educational foundations, including renowned schools and colleges (Brock \& Kim, 2011).

Austin, Stevenson, and Way-Skillern (2006, p. 3) argue that the fundamental purpose of social entrepreneurship is to create a social incentive for the payment of government bonuses, while the main reason for existence is to perform tasks that generate profit in the business entrepreneurship. In simpler terms, social entrepreneurship can be characterized as "an innovative movement, in which social intention is embedded" (Austin et al., 2006, p. 1). The focus of social entrepreneurship is the search for adequate answers to social questions. Consequently, the creation and maintenance of social qualities in people were perceived as an important thought (Prasodjo, 2013, p. 207).

Social entrepreneurship has a positive effect on poverty reduction and social critical thinking. Research has shown that social entrepreneurship has a large financial impact, especially in solving cultural problems. We argue that certain character traits are important in representing social problems. Individuals with individual activism can use their previous information, initiative and resourcefulness, and experience to prepare for social ventures that have a social impact (Nsereko et al., 2017).

For over twenty years, the accepted model for the development of social needs has been the government's approach to expanding administrative activities that emphasized the details of governance models and focused on government revenues, with indistinguishable administrations being closed to the region and outsourced to various NPOs (non-profit organisations) through the government. With government cuts and its changing theory of government aid, administration experts needed to explore new intentions to meet new social 
needs.

\subsection{Problem Statement}

As Torrecchia (2013) defined Social Accounting as a tool of Corporate Social Responsibility (CSR), it can be said that the existence of this tool has been compromised in Pakistan. There has been limited research on the existence and compliance of CSR in Pakistan and this scarcity of academic literature has resulted in the absence of social accounting in Pakistan. Even after various organisations such as United Nations Development Program (UNDP), Pakistan Centre of Philanthropy (PCP) and Responsible Business Initiative (RBI) engaging in CSR activities, there has been little attention provided to this sector of business activities. Moreover, back in the past, very minimal laws saw the light of the establishment to check for CSR compliance and implementation (Newspaper, 2013).

Businesses in Pakistan practice reactivity than proactivity in the cases of natural disasters which further demonstrates their internal attitudes toward the social cause that they need to play in the lives of the people that they serve (Yunis et al., 2017). Business owners fail to show any keen interest in informing the outcomes that their actions have had on the lives of people. Due to weak CSR compliance and interpretation, Pakistan has witnessed a staggering growth in social accounting. Molecke and Pinkse (2017) stated that some businesses do not want to be held accountable for any damage done to the social environment by their activities. Furthermore, it has been noted that only those businesses engage in CSR activities that have some kind of involvement in occurring natural disasters (Linnenluecke \& McKnight, 2017).

With that been said, such businesses tend to practice social accounting with acute diligence, in that they mask their poor actions with the philanthropic work done during disaster situations such as earthquakes, floods and war situations (Nolan \& Frishling, 2020).Social accounting is of high significance to the businesses in Pakistan. Public knowledge about how businesses work has increased over an extended period. People have started to become more aware of the actions taken by organisations in particular situations. For this reason, businesses are required to practice social accounting to bring into the public's knowledge of the value created by their products or services (Kocollari \& Lugli, 2020).

The reason to conduct this research is to bring to the forefront the concept of CSR across Pakistan. Social accounting, due to the vague existence of CSR is relatively underdeveloped in Pakistan. Thus, it needs to be brought within the sight of not only the businesses but also the public so that they can know what to expect from businesses. And what can be classified as acceptable and non-acceptable behaviour from the side of organisations. Also, through this essay, firms can be able to develop enhanced CSR policies to further improve the process and outcomes of social accounting.

\subsection{Gap Analysis}

There have been several empirical pieces of research conducted on Social Accounting initiatives (Koli \& Rawat, 2012; Koli \& Rawat, 2020; Stevenson \& Sundberg, 2014) explaining the importance of social accounting and how certain factors might influence this activity within organisations both positively and negatively. Stevenson and Sundberg (2014) 


\section{MInstitute Macrothink $_{\text {Int }}$}

International Journal of Management Innovation Systems

ISSN 1943-1384

2021, Vol. 6, No. 1

based their study in Sweden which is a developed country far ahead of Pakistan which is a developing country. Through this study, an idea will be provided about the concept of social accounting in developing countries like Pakistan and many others. The study of Stevenson and Sundberg (2014) investigated the difficulties faced by social enterprises in conducting social accounting and also acknowledged an existing gap regarding the implications within small-medium enterprises.

The study of Pejic Bach et al. (2018) investigated factors determining entrepreneurial intentions in Slovenia. In this study, the theory of planned behaviour and an innovative cognitive style was applied to discuss the concepts in detail. A sample of 330 bachelor and master students in economics and business were recruited for this study and were distributed survey questionnaires to provide their responses. According to the findings of this study, entrepreneurial intentions are positively related to an individual's attitudes in regards to entrepreneurship, subjective norms and perceived behavioural control. However, this study failed to align the entrepreneurial intention with social accounting, sustainability and corporate social responsibility. In this case, this research fills the gap by covering all the three aspects concerning the attitudes of individuals toward entrepreneurial intentions.

Empirical research conducted by Killian and O'Regan (2016) to explore the extent to which social accounting has the potential to generate legitimacy for a company in the local community of Ireland. Moreover, the study also looked at the roles of the community in the process of social accounting. The authors of the study conducted interviews with both the companies and community performers to generate results for their study. The study employed the Bourdieusian framework to highlight the roles played by the distinctive performers to aid in the creation of a local account as well as provide the company with an authoritative position. As per the study, social accounting acquires symbolic power, in that the company with higher authority engages highly in the process and the lower ones in authority might or might not follow their footsteps.

However, the research of Killian and O'Regan (2016) failed to examine and investigate the attitudes of employees within the companies. Attitudes of individuals tend to influence their behavioural intentions. Despite social accounting having an association with behavioural intention, Killian and O'Regan (2016) did not consider investigating the influence of personal characteristics on the social accounting process. This gap will be bridged through this research as the researcher has chosen moral, pragmatic and cognitive dimensions of attitude to investigate the impact these attitudes have on the social accounting process. To add on, the impact of entrepreneurship personal characteristics on the attitudinal dimensions will be investigated and hence linking them to the process of social accounting.

Killian and O'Regan (2016) focus more on the process of social accounting than the output of the process in their study. The authors adopted primary research for their study through the use of varied semi-structured interviews. The authors of this study did not consider employing survey research into their study. Survey research would have helped them to reach out to a bigger sample and hence save their time from interviewing many people. Moreover, survey research would have allowed them to compare the interview and survey results. This 
gap is however covered in this research where the researcher surveys 75 firms using close-ended questionnaires to obtain from the participants, responses relating only to their business and not in any other context.

To add on, literature has very limited research conducted on social accounting in developing countries. This implies that developing countries have not yet reached to the compliance of CSR activities and hence sustainability. Gull et al. (2013) researched on social accounting in India, however, they based their research on theoretical surfaces and did not conduct any primary research to support the data retrieved from literary sources. The authenticity of their information was not valid and hence this research.

Hence, this is a novel attempt as no previous study attempted to explore the effect of wide range of personal characteristics on social media accounting using survey methogology. Moreover, no previous study offered to explain this in Pakistani context. Hence, this would further extend the research frontier and provided a much needed generalisation of social accounting literature.

\subsection{Research Objectives}

This research study seeks to identify the social entrepreneurship profile that highlights the specific personal characteristics of employees working in organisations. Also, this study attempts to understand how the broader initiatives that help today's organisations become more socially responsible. The factors covered in personal characteristics include 1. Sociality, 2. Innovativeness, 3. Market-orientation, and 4. The ability to identify New Opportunities (INO). The Social Accounting Initiatives included in the study areInternal Attitude (IA), and Subjective norms (SN), each is classified as 1. Pragmatic, 2. Moral, and 3. Cognitive, as well as Perceived Behavioural Control (PBC). In line with the personal characteristics as well as the social accounting initiatives, the following objectives were set for this study: RO1: To develop an understanding of social entrepreneurship and social accounting RO2: To develop an understanding of the scope of social accounting initiatives in Pakistan RO3: To examine the impact of the social initiatives on the socially responsible nature of businesses RO4: To formulate strategies to improve corporate social responsibilities of organisations in Pakistan

\subsection{Research Question}

Main Research Question: What impact do personal characteristics defined by the social entrepreneurship profile have on the social accounting initiatives?

RQ1: What is the impact of sociality, innovation, market-orientation and identification of new opportunities on pragmatic internal attitude?

RQ2: How is moral internal attitude influenced by sociality, innovation, market-orientation and identification of new opportunities?

RQ3: What significance do the various personal characteristics have on cognitive internal attitude?

RQ4: What impact do the social entrepreneurship personal characteristics have on perceived 
behavioural control?

\subsection{Significance}

This study seeks to explain the attitudes of decision-makers across different firms and how these attitudes affect their intentions in the engagement in the social accounting process. Also, through this research industries will understand the reason as to why social accounting is mostly practised in small organisations and hence contributing to future development and progress. Furthermore, organisations will be able to develop policies that will encourage employees to take part in the social accounting process after having a complete examination of the attitudes of the employees. By engaging in the social accounting process, organisations will be creating higher customer value and hence will generate more profits giving them tangible benefits of profitability. The findings of this study highly contribute to the field of social accounting especially in the profit sector for small and medium-sized firms.

\section{Theoretical Framework and Literature Review}

\subsection{Social Entrepreneurship}

Social entrepreneurs are the heads of ordinary people who achieve remarkable efforts and results (Morse \& Dudley, 2002; Verma, 2009; Brooks, 2009). Social and exemplary entrepreneurs have almost the same qualities as the ability to transform businesses with their sharing abilities. In addition, social entrepreneurs solve problems in the public arena (Mair \& Marti, 2005). For example, the social entrepreneurs constantly snatch opportunities that others overlook and try to improve the structure of social orders, motivate new methodologies, find more effective approaches to transferring the benefits of the network, and continually strive to improve cultural conditions (McConash \& Simpson, 2003; Mayr, Marty, 2005; Aman Shah, Mohd Ali, 2008; Brooks, 2009).

The social entrepreneurship hypothesis, created by Nicholls and Cho (2008), characterizes social entrepreneurship as a progression of authoritative exercises in three key classifications: sociality, promotion, and market direction.

Todres and Lewis (2012) characterized social entrepreneurship as follows: "By sociality we mean the connections, associations, correspondence, professions and organisations, and social and social standards that drive business development." According to Todres and Lewis, short-term or long-term relationships between partners are the foundation of (social) entrepreneurship. Thus, the social component is expressed in a specific environment in which entrepreneurship operates, which is characterized by social ties and organisations.

The fruitful combination of social needs and market opportunities is perhaps the biggest challenge for some types of social entrepreneurship. In most cases, a reasonable course of action may not be entirely clear, and achieving achievements, including achieving the required minimum amount, presents huge challenges that can reduce an incredible number of SE actions. Thus, even a victorious thought can fail. SE regularly needs to change its usual business in the market in order to penetrate the market.

The possibility of social advancement - for example, the promotion of subjects, management, 


\section{Mll Macrothink}

International Journal of Management Innovation Systems

ISSN 1943-1384

2021, Vol. 6, No. 1

cycle and management that meet social needs - has generated tremendous enthusiasm in recent years among numerous orders and professional circles. The opportunity for social development has been used to indicate "a pathway to create, help and actualize new responses to social needs and problems" (Phills et al., 2008).

It is an idea related to showcasing individual entrepreneurs in social business and the act of social entrepreneurship, with an emphasis on the creative use and combination of assets to meet social needs and influence social change (Martin \& Osberg, 2007). It is legitimately identified with the study of social obligations at the human and authoritative levels to identify the socially innovative demonstrations of people employed in social business, or gatherings of heroes in ordinary society trying to advance certain social missions (Yuen, 2011).

At the heart of social entrepreneurship is the recognition of discoveries, or simply the recognition of open doors. Some researchers argue that the opportunities for social entrepreneurship are different from those for income-driven enterprises (Mair \& Nooba, 2006; Robinson, 2006). With the development of "entrepreneurship" as an independent field of research and an unmistakable field of business, it became necessary to separate from management (Shane \& Venkataraman, 2007). One idea — the recognition of opportunity and abuse - seems particularly relevant because it encompasses a wide range of behavioural attitudes, such as risk-taking, innovation, or efficiency, that research has shown are widespread among business people.

Many documents survived in administrative records for the public environment (Ansell \& Gash, 2012; Hazy, 2012), and the pioneer function was found to have a "cumulative effect" (Kania \& Kramer 2011, 2013). Building on existing written work and new accurate experiences of community-led social entrepreneurship, authoritative research at various levels of activity can perhaps fabricate comprehensive information in this area. Cultural leaders are concerned about the primary responsibility of the social business visionary for sociopolitical change and how that commitment subsequently shapes their relationships with various social actors. A social business person can feel a shared responsibility and ownership by putting a social purpose in the hearts of the respective social actors.

\subsubsection{Social Entrepreneurship Profile}

The viewpoint of individual attributes or character is one of the early old-style approaches in entrepreneurship. It is a profoundly dubious territory of study as a result of the enormous number of innovative character qualities. Character attributes, which can impact a person's assurance and method of acting, have additionally been discovered to have corresponded with information, abilities and capacities, mission and activities of business creation, and business achievement (Rauch \& Frese, 2007; Ahmad, 2009; Nga \& Shamuganathan, 2010).

According to Nicholls and Cho (2008), social entrepreneurship is a series of organisational activities that cover three important categories of socialism, innovation and market orientation. Socialism is a dimension in which an organisation works intending to achieve effective social objectives effectively (Nicholls \& Cho, 2008). Nichols and Cho's statements coincide with Marshall's study (2010), and Nga and Shamuganathan (2010) agree that the 


\section{Mll Macrothink}

International Journal of Management Innovation Systems

ISSN 1943-1384

2021, Vol. 6, No. 1

organisation of social entrepreneurship contains a real social element that embodies an explicit social mission that will affect how social entrepreneurs perceive and assess opportunities.

Besides, social entrepreneurship is based on the dimensions of innovation. Social entrepreneurs are the agents of change for their communities where they will take advantage of opportunities that others do not realize such as trying to improve the system in society, creating a new approach, catalyzing change and creating a resilient solution to the good of the global community (Hariyaty, 2014; Nicholls \& Cho, 2008). Market orientation is characterized as a new manifestation of social entrepreneurship aimed at solving cultural problems while simultaneously generating budget revenues.

The expected development of explicit personality traits includes recognition of discovery, synergistic management style, collaboration and network inspiration, which are reflected in the characteristics of a social entrepreneur (Morse \& Dudley, 2002). Turner and Martin (2005) have demonstrated that networked businesses associated with social entrepreneurship require administrative and innovative capabilities, such as the ability to control spending plans, verify results, and control reserves. From an entrepreneurial perspective, creators demonstrate a willingness to take risks, mobilize support, associations and organisations, and transfer creative work. Various scholars have noted the importance of the ability to manage (Alvourd et al., 2004; Sharir \& Lerner, 2006; Thompson et al., 2000) and the ability to collaborate (Morse \& Dudley, 2002).

The social entrepreneurial profile is divided into SPCSE (specific personal characteristics of social entrepreneurs) and SEO (social entrepreneurship organizing) activity.

\subsubsection{Sociality}

Sociality includes issues related to camaraderie, socialisation and hobbies (Nicholls \& Cho, 2008). As Nicholls and Cho pointed out, sociality is the level of collaboration of an association trying to successfully achieve social goals. Sociality in SEO is characterized as a way of organizing and guiding a movement, as well as achieving cultural goals through initiative exercises. Meanwhile, advancement is the ability to rethink and improve human life by applying innovative answers to problems and opening up new opportunities. Development changes open positions in market thoughts (Nicholls \& Cho, 2008).

\subsubsection{Market-Orientation}

Market orientation is defined as implemented social entrepreneurship activities (Nicholls \& Cho, 2008). Whether the presence of these social entrepreneurial characteristics in organisational employees leads to the improved total social impact of business needs to be researched (Stevenson \& Sundberg, 2014). Emerson (2003), Dierkes and Antal (1986) and Lingane and Olsen (2004) emphasize that to reach a sustainable business, social values have to be fully incorporated and centralized in the business process and should not be considered a peripheral process. 


\subsubsection{Innovation}

Social entrepreneurship is based on the dimensions of innovation. Social entrepreneurs are the agents of change for their communities where they will take advantage of opportunities that others do not realize such as trying to improve the system in society, creating a new approach, catalyzing change and creating a resilient solution to the good of the global community (Hariyaty, 2014; Nicholls \& Cho, 2008). Social entrepreneurs are not like profit-oriented business entrepreneurs, but they are motivated to improve society, become agents of change for society, take advantage of opportunities that others do not realize to improve the system, create new approaches and seek solutions to transform society towards more life well. The souls of social change agents owned by them will be more 'altruist' by focusing on solving community problems innovatively.

\subsubsection{Identifying Opportunities}

Opportunity recognition is often connected to the process of perceiving an opportunity (Krueger, 2005). The foundation of any considerations of sustainability lies in the normative perception of sustainability and CSR (Hahn \& Kühnen, 2013). Based on this, the specific corporate performance in the area of sustainability and CSR can be measured utilizing sustainability accounting. The accounting then serves to support decision making concerning corporate sustainability initiatives (Hahn \& Kühnen, 2013).

\subsection{Social Accounting}

Different stakeholders are now showing a higher interest in organisations' social responsibility than ever before. Even though ideas of social reporting have been around since the 1960s (Dierkes \& Antal, 1986), different stakeholders are now showing a higher interest and involvement in organisations' social responsibility than before (Barraket \& Yousefpour, 2013). This external demand pushes organisations to take greater social responsibility and also disclose on it, a fact that has, according to Hahn and Kühnen (2013), led to more frequent reporting on corporate social responsibility.

In these reports organisations promote their social and environmental actions (Hahn \& Kühnen, 2013). To reach a sustainable business, social values have to be fully incorporated and centralized in the business process and should not be considered a peripheral process. Seidler and Seidler (1975, cited in Koli \& Rawat, 2012:31) define social accounting as a "modification and application of conventional accounting to the analysis and solution of problems of a social nature". Pearce (2001: 9, cited in Gibbon \& Dey, 2011) explains the term as: "a framework which allows an organisation to build on existing documentation and reporting and develop a process whereby it can account for its social performance, report on that performance and draw up an action plan to improve on that performance, and through which it can understand its impact on the community and be accountable to its key stakeholders".

The framework is based on Ajzen's Theory of planned behaviour (TPB) that highlights three independent factors that influence the intention to perform a behaviour: attitudes, subjective norms and perceived behavioural control. Instead of categorizing attitudes based on Ajzen's (2005) cognitive, affective and conative nature, the TPB is complemented with Suchman's 


\section{Macrothink}

International Journal of Management Innovation Systems

(1995) three types of legitimacies: pragmatic, moral and cognitive.

Thus, the framework constitutes six elemental attitudes of the legitimacy of sustainability, internal morale, internal pragmatic, internal cognitive, external moral, external pragmatic, and external cognitive as well as the perceived behavioural control.

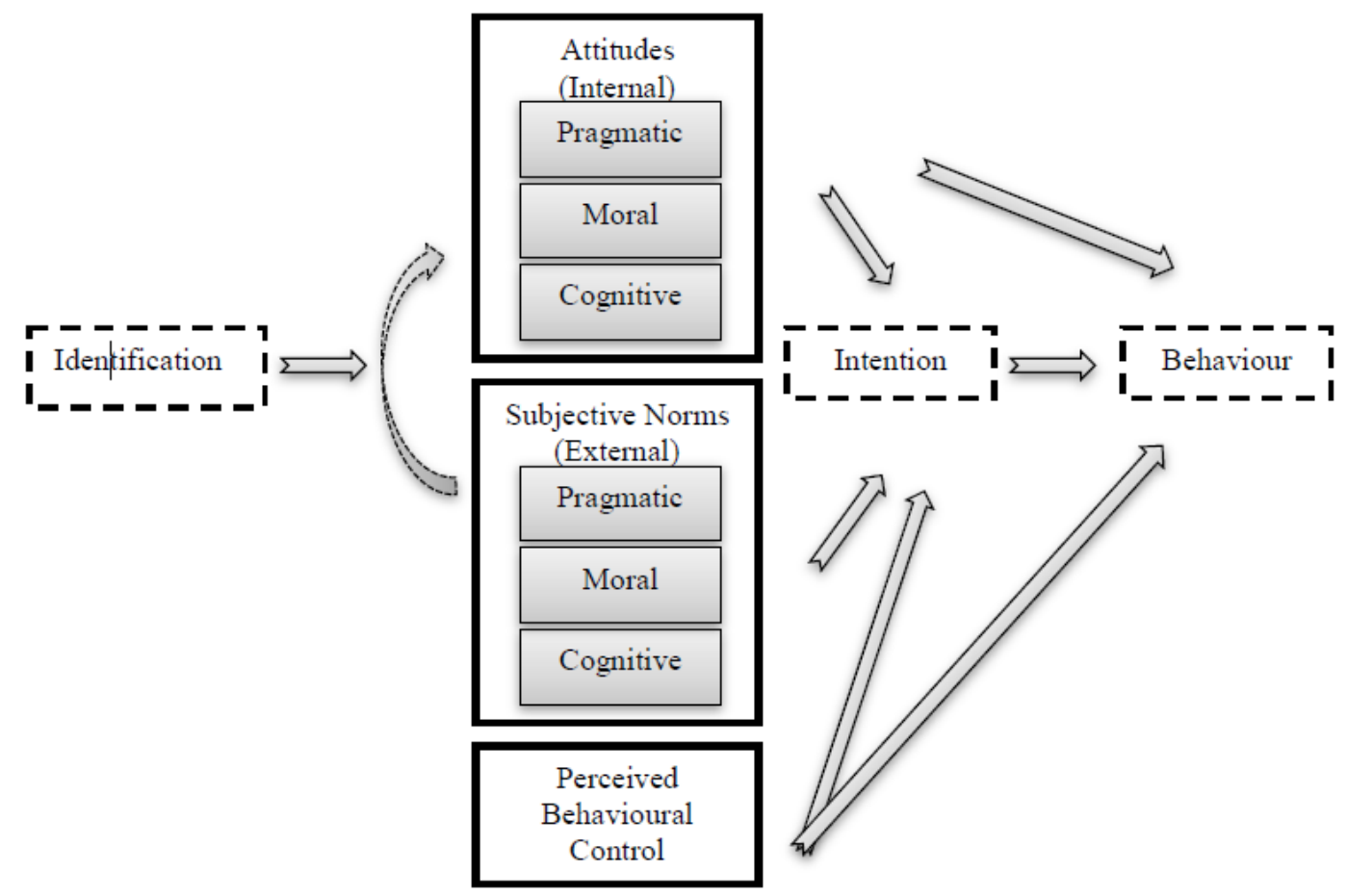

Figure 1. Legitimacy in the Theory of Planned Behaviour (Thomas \& Lamm, 2012)

The forms of legitimacy identified by Suchman (1995) are: pragmatic, based on the self-interested calculations of an organisation's audience; moral, based on a normative evaluation of the organisation and its activities; and cognitive, based on comprehensibility and taken-for- grandness. These forms of legitimacy do not differ significantly from Ajzen's (2005) attitudes. For example, the cognitive nature described by Ajzen (2005) appears to be similar to the cognitive legitimacy presented by Suchman (1995).

Further, the affective nature that regards feelings and evaluation can be related to moral legitimacy. However, when comparing the remaining categories; the pragmatic legitimacy and the conative nature, Ajzen's (2005) and Suchman's (1995) typologies become very distinct from one another. Whereas the pragmatic legitimacy regards the evaluator's self-interests and perceived benefits, the conative nature regards behavioural intentions towards an attitudinal object. Nevertheless, it appears that ideas of legitimacy and ideas of attitudes in scholarly literature are closely interlinked.

\section{The Social Accounting Dimensions}

Ajzen (2005:118) declares that "Generally speaking, people intend to perform a behaviour when they evaluate it positively when they experience social pressure to perform it, and when 
they believe that they have the means and opportunities to do so." Most social psychologists agree that an attitude is evaluative. This means that "an attitude is a disposition to respond favourably or unfavourably to an object, person, institution, or event" (Ajzen, 2005: 3). Since attitudes cannot be seen by observation, Ajzen (2005) stress that they must be determined by measurable responses that reflect positive or negative evaluations of the attitude object. Ajzen (2005) also states that these responses can be cognitive, reflecting perceptions of the object and beliefs about its characteristics; affective nature, which reflects feelings and evaluations; and conative nature, referring to intentions and actions concerning the object. The framework of the Theory of Planned Behaviour highlights six elements of Social Accounting.

\subsubsection{Pragmatic Internal Attitude}

There has been a lot of disputes in existing literature regarding the reference of pragmatism as an attitude. In literature, pragmatism is seen both as a theory of truth and an attitude that links different pragmatists together (Cutchin \& Dickie, 2012). Martela (2015) has defined pragmatic attitude as one of looking away from the supposed necessities and rather look toward the last things like the outcomes and consequences of an action. Such an attitude, if inherited by employees within an organisation can aid in the development of positive behaviour toward the goals of the organisation. Employees will be more focused toward achieving the goal, which is the outcome of their action (Tims \& Bakker, 2010). Research conducted by Reynolds (2004) talked about humanism as the core element of pragmatism. This can further be related to organisational dimensions, in that employees seek to learn from their experiences. Humanism acknowledges that the only thing man has is the human experience (Honnacker, 2018). Prior experience will encourage employees to work for the betterment of the organisation and hence be more socially responsible.

Sociality, in the context of humans, has been defined as the aptitude of obtaining core norms of behaviour and succeeding obligatory rules when tacit and perceived to be authentic (Shin \& Hancer, 2016). Regarding the study of Martela (2015), pragmatism has been seen both as a theory of truth and an attitude. Integration with the societal values and people creates an element of humanism within individuals from which they gain experience. About the study of Reynolds (2004), it can be said that sociality does have a significant impact on pragmatic internal attitude as individuals use their prior experiences to make decisions and plan behavioural actions. This is further supported by the Theory of Planned Behaviour. Thus, it can be said that the above hypothesis is true.

\section{H1= sociality has a significant and positive effect on pragmatic internal attitude}

There is a significant relationship between innovation and pragmatic internal attitude, in that pragmatism bases its claims on practical implications rather than theoretical knowledge. Similarly, innovation is a result of continuous improvements in a particular product, method or service (Svasta, 2017). The practicality of both the concepts states that with the introduction of innovation, individuals will make use of their prior experiences to determine whether innovations will benefit the organisation or not (Sultanova, 2020). Also, Pyka (2017) stated that innovation creates an open mind and allows for the acceptance of diversity and interdisciplinarity of employees. Moreover, innovations enhance opportunities for employees 
which positively impacts their attitude.

\section{H2= innovation has a significant and positive effect on pragmatic internal attitude}

Businesses often become market-oriented, in that they show greater concern toward creating value for the customers through certain actions and competitive advantage. According to Yang et al. (2010), businesses can only gain and sustain a competitive advantage when its employees are motivated to perform in a superior manner. Tradeoffs between the external environment and strategic initiatives create high value for the customers and the business (Grover \& Kohli, 2013). In relation to the study of Bhattarai et al. (2019), the above hypothesis can be supported, in that market-orientation is significantly related to pragmatic internal attitude.

\section{H3 = market orientation has a significant and positive effect on pragmatic internal attitude}

With reference to the theory of planned behaviour, employees plan their actions and behaviours according to their previous experiences as well as through the use of knowledge about prospects (Baumeister et al., 2016). New emerging possibilities in the organisational environment give room to individuals to validate their thought process. This validation enables the construction of a positive attitude toward the operating ways of the business. Furthermore, the emergence of new opportunities allows individuals to think about the applications of their prior experiences in the current scenario and also to learn new concepts using the present situations. This enhances pragmatic internal attitude and hence supporting the above hypothesis.

\section{H4= identifying new opportunities has a significant and positive effect on pragmatic internal attitude}

\subsubsection{Moral Internal Attitude}

The evaluation of behaviour based on moral principles by an individual is commonly known as moral attitudes (Luttrell et al., 2016). Research has suggested that moral attitude stems from moral conviction, in that an individual makes decisions by sensing the ultimate difference between the right and the wrong (Brandt \& Wetherell, 2012). Business organisations have established policies to aid in the differentiation between the right and wrong actions on the side of both the managers and employees. An individual that has an underlying sense of knowledge about the right and wrong will always act in accordance to the established policies and hence prove to be socially responsible both toward the business and its customers (Vercic \& Coric, 2018). Moreover, Huhtala et al. (2019) have identified that moral attitudes are internalized moral rules or values that enable an individual to work in a morally correct manner. Many organisations conduct CSR activities with employees that demonstrate morally correct attitudes to support the views of the business and its reputation in the public's eye (Lee \& Ha-Brookshire, 2020).

The humanism concept of sociality supports the idea that behaviours are adopted when the norms of those behaviours are authentic. Referring to the study of Brandt and Wetherell 
(2012), moral attitude comes from the fact that individuals are morally convicted to differentiate between the right and wrong. Policies, rules and regulations established by organisations can sometimes be against the moral definitions of employees working in the organisation. The internally established moral values of an individual may certainly not be influenced by sociality, in that people will always act according to what their definition of right and wrong is and not on the pressure of society. With this being said, the above hypothesis has not been supported highly by existing literature and it is from this research that this gap can be bridged.

\section{H5= sociality has a significant and positive effect on moral internal attitude}

Innovations are not just a contribution to society and the economy but also result in fundamental shifts within society. The values and ideas about oneself and the world are challenged by the progression of innovations (Smorodinskaya et al., 2017). There is a moral responsibility towards the introducers or producers of innovations. According to the study of Long et al. (2020), innovations come with new procedures and ways of managing businesses. This affects the moral attitudes of people, in that new moral perspectives and vocabularies are formulated to adhere to the innovations made (Usai et al., 2018). Thus, the above hypothesis is supported by the existing literature and through this research, it has been built upon in a greater context.

\section{H6= innovation has a significant and positive effect on moral internal attitude}

When businesses are more aligned towards their customers and the environment, there is a greater positive attitude advocated the process of social accounting (Peifer et al., 2020). Business employees are motivated by the actions of their superiors like the managers or team leaders. What they perceive as the right actions of the top management is what they inherit in their behaviour and hence practising morally right actions. With reference to existing literature, it can hence be said that the above hypothesis is true and supported by public information as people are morally motivated to keep a positive attitude by engaging with the requirements of the market and how they create value for the business (Thi \& Ottar, 2016).

\section{H7 = market orientation has a significant and positive effect on moral internal attitude}

According to Hilton (2017), an attitude with the label moral increases in strength and value and hence contribute highly to an emerging body of work. The study of Jamali and Karam (2018) argued that social accounting entails various opportunities for businesses to grow in the eyes of the public and create positive and healthy environments for the employees to work in. Moreover, with the identification of new opportunities, employees have a clearer view of what behaviour is required in certain situations. Hence, the above hypothesis is supported by existing literature and the Theory of Reasoned Action, in that individuals reason their behaviours under the opportunities and situations that they face rationally.

\section{H8= identifying new opportunities has a significant and positive effect on moral internal attitude}




\subsubsection{Cognitive Internal Attitude}

Changes in one's attitude stem from the elements of cognition in attitude. The cognitive dissonance theory proposed by Leon Festinger in 1957 states that people tend to change their attitudes due to conflicting beliefs and behaviours (Harmon-Jones, 2019). Conflicting attitudes tend to result in mental discomfort in individuals and to overcome this discomfort, alterations are made to the conflicting attitudes (Lavergne \& Pelletier, 2016). According to the cognitive dissonance theory, people have an inner drive to avoid disharmony in attitudes and hence improve cognitive consistency. Inconsistency in attitudes results in the urge to make changes to eliminate the disharmony or dissonance (Yadav). Forced compliance behaviour, decision-making and effort are some of the identified causes of cognitive dissonance. In organisations, employees are often forced to comply withbehaviours that they do not want to. This creates a drive within them to change a particular section of their attitude to bring progress to the organisation.

Individualistic experiences as a result of sociality lead to changes and modifications in attitudes to adhere to the requirements of a particular situation (Bayerl et al., 2016). Leon Festinger's (1957) theory of cognitive dissonance has argued that conflicting beliefs and behaviours are what lead to changes in the attitudes of an individual. In the context of sociality, people connect and share information to form cooperative social groups (Tomasello, 2020). The study of Lavergne and Pelletier (2016) found that while people are engaging with each other, there tends to be the introduction of disharmony and discomfort due to conflicting attitudes. To conform with the social groups, alterations are made in the attitudes to perform appropriate behaviour in relation to that of the social groups. This is known to prove cognitive consistency. Thus, the above hypothesis is supported by the fact that people communicating in social groups change attitudes to suit their cognitive mindsets.

\section{H9= sociality has a significant and positive effect on cognitive internal attitude}

The cognitive component of attitude does not come in isolation but rather is referred to as the beliefs and attributes associated with an object (Siciliano et al., 2017). Innovations result in the production of new products and methods that tend to impact the way individuals react to them. Employees within an organisation adapt to innovations in a way that they shape their behaviours in line with the requirements of the innovation process. Hence, the above hypothesis is supported regarding the research of Judge et al. (2017).

\section{H10 = innovation has a significant and positive effect on cognitive internal attitude}

Cognition relates to the association with a particular object or product as identified in the research of Peifer et al. (2020). According to the study of Thi and Ottar (2016), businesses that seek to identify their customer needs and wants impact highly on the attitudes of employees. Employees of such organisations attribute their behaviours and attitudes towards the betterment of both the customers and business. Similarly, caring for society and practising CSR with full compliance has led to the emergence of positive cognitive internal attitude (Yang, 2018). Thus, the above hypothesis is true implying that market-orientation and cognitive internal attitude have a significant relationship. 
H11 = market orientation has a significant and positive effect on cognitive internal attitude

The continuous advancements in technologies have led to the emergence of new opportunities with an expansion of the working body in the professional environment. According to the theory of planned behaviour, employees base their reactions and behaviours on their experiences (Rottger et al., 2017). Previous experiences of employees help them carry lessons to the new opportunities and by associating to the new opportunity, they demonstrate a tendency to modify their attitude and plan behaviours accordingly (Tasselli et al., 2018). Referring to literature, the above hypothesis is supported, in that emerging opportunities bring a change in the cognitive internal attitude to adapt to the new situation.

\section{H12 = identifying new opportunities has a significant and positive effect on cognitive internal attitude}

\subsubsection{Pragmatic Subjective Norm}

Shin and Hancer (2016) have defined subjective norms as beliefs that lead to the approval and support of particular behaviours. Social pressure is perceived to be the motivating factor for subjective norms (Ferri et al., 2019). The concept of pragmatism argues that reality is not a one-time determination but rather something that always works. Pragmatic subjective norm implies that people will support only those behaviours and attitudes that result in satisfactory relations with various parts of one's experiences (Kaushik \& Walsh, 2019). The research of Watts et al. (2019) suggested that pragmatists tend to choose one version of reality over another based on its perceived or desired outcomes. For example, Kaushik and Walsh, (2019) describe an object with a flat surface and four legs as one used differently by the positivistic researcher and constructivist researchers. The latter would use the object depending on the need and situations as both a table and bench while the former would use it only as a table due to underlying perceptions. In the case of businesses, managers and their employees will engage in behaviours that will bring out the best of outcomes and hence put support fully on that particular behaviour.

The above hypothesis is supported by literature, in that human experience through socialism exposes individuals to various kinds of behaviours coming out from different people under different circumstances. According to Shin and Hancer (2016), pragmatic subjective norms are those that influence the behaviours of an individual depending on the outcome or result of a certain concept or relationship. While interacting with different people and forming cooperative social groups, people make a choice of one reality over the other depending on the perceived or desired outcomes. In this way, the research conducted by Watts et al. (2019) stated that the attitudes of an individual are influenced by the people that they interact with and in according to the manner and nature of the interaction.

\section{H13= sociality has a significant and positive effect on pragmatic subjective norm.}

Pragmatic subjective norm implies that people only abide by social pressure and values when the outcomes are according to what they desire. For instance, the study of Smith et al. (2018) suggested that through innovation organisations set, for their employee's certain rules and 
regulations that if agreed upon by the employees will generate positive behaviours hence supporting the above hypothesis.

\section{H14= innovation has a significant and positive effect on pragmatic subjective norm}

Market-orientation also referred to as the acknowledgement of customer needs and wants to bring advancement to the organisation as the customers start to value the services provided by the organisation. The attitudes of employees in relation to others often affect the behaviours performed by certain employees. Pragmatic legitimacy like the tendency of reduced costs result in the overpowering of pragmatic attitudes in comparison to the moral attitudes (Stevenson \& Sundberg, 2014). In this way, the above hypothesis is supported by the existing literature.

\section{H15= market orientation has a significant and positive effect on pragmatic subjective norm}

Social accounting measurement is key to sustainability management as well as taking full advantage of the emerging opportunities (Stevenson \& Sundberg, 2014). Businesses create value for customers by not only fulfilling their wants and need in terms of product and service delivery but also by taking care of the surrounding environment (Evans et al., 2017). Global climate change has resulted in new opportunities for businesses to showcase their services in the social cause sector, in that they need to take measures to reduce negative impacts of their operations on the society at large. Employees will be more attracted to high pays while working for new opportunities (Block et al., 2018). This brings a change in their attitude and behaviour performance leading the researcher to the above hypothesis.

\section{H16= identifying new opportunities has a significant and positive effect on pragmatic subjective norm}

\subsubsection{Moral Subjective Norm}

The subjective norm of morality states that the moral authority abides within the individual (Shin \& Hancer, 2016). Research of Han et al., (2017) defined subjective norm as a human reason by which man captures his coherent nature and its indispensableassociations as a norm of moral action. Ajzen's (1991) theory of planned behaviour did not include the moral dimension into it. However, as stated in the research of Shin and Hancer (2016), Ajzen did make recommendations to include the moral concept when studying the behaviour of individuals. With respect to the theory of planned behaviour, individuals test a particular act in terms of its morality and create conclusions or judgements on how good or evil that act is (Liu et al., 2020). Employees, within an organisation, tend to hold moral authority regarding certain actions and make decisions by relying on their rational nature following moral norms (Qin et al., 2018).

With reference to the study of Awad et al. (2018), an individual's moral behaviour stems from their definition of right and wrong rather than the explication of the external environment. The existing literature does not support the above hypothesis as the theory of planned behaviour has no implications of the moral aspect of attitude and behaviour in its 
explanations. Therefore, this research fills this gap in the literature.

\section{H17= sociality has a significant and positive effect on moral subjective norm.}

Concerning the study of Stevenson and Sundberg (2014), innovations result in the increasing need for social accounting as new technologies come with new impacts on society. Furthermore, the attitudes of other people in an organisation tend to affect the behaviour of a specific employee. For example, Stevenson and Sundberg (2014) stated that innovation brings up new and different social impacts on society and peers and authorities within an organisation acknowledge the importance of reporting these social impacts. In that case, the employees are morally induced into doing the right thing by communicating the impacts with the top management. This further leads to the acceptance of the above hypothesis.

\section{H18= innovation has a significant and positive effect on moral subjective norm.}

When many areas of a specific organisation are linked with the market and there is a line of communication between the two, employees begin to ponder upon the fact that their peers and authorities of the organisation believe that the actions of an employee will have equal impact on the needs of the customer (Rezaei et al., 2007). In order to work in the best interest of the audience of the organisation, individuals modify their attitudes to suit the moral subjective norms within the organisation hence supporting the above hypothesis.

\section{H19= market orientation has a significant and positive effect on moral subjective norm.}

The identification of emerging opportunities within an organisation has resulted in higher pragmatic attitudes than moral attitudes. According to Stevenson and Sundberg (2014), pragmatic legitimacy can overpower moral attitudes as outcomes, consequences or desired results influence the attitude of employees more than the difference between right and wrong. In this way, employees tend not to abide by the moral principles of the organisation and thus deviate from the practice of social accounting or CSR (Afsar et al., 2020).

\section{H20 = identifying new opportunities has a significant and positive effect on moral subjective norm.}

\subsubsection{Cognitive Subjective Norm}

Cognitive theories such as the theory of Reasoned Action (Fishbein \& Ajzen, 1975) has failed to provide adequate information regarding how personal decisions are made and how they affect the behaviour of an individual (Schunk \& DiBenedetto, 2020). In the organisational setup, decisions cannot be made on free will as that can result in massive destructions in the way the particular organisation functions. According to the concept of cognitive subjective norm, individuals have embedded into themselves a dynamic constraint of satisfaction in which interaction between prior beliefs and current social experiences takes place (Ham et al., 2015). The connectionist mechanism enables individuals or employees to make understandable personal and professional decisions (Science Direct, 2016). The relationship between cognition and subjectivity creates the possibility for organisations to work in line with the social causes that aid in the development and maintenance of the environment. 


\section{MInstitute ${ }^{\text {Mank }}$}

International Journal of Management Innovation Systems

ISSN 1943-1384

2021, Vol. 6, No. 1

Fishbein and Ajzen's (1975) theory of Reasoned Action has described very briefly how individuals make personal decisions and what impact these decisions have on the behaviour of an individual. Through engagement with fellow peers to create a cooperative social group, individuals or employees link their prior experiences with the current social scenarios and tend to make decisions based on this connection (Schunk \& DiBenedetto, 2020). To attain the satisfaction needed in the cognitive subjective norm, individuals connect with the concepts of objectivity and subjectivity to shape their behaviours. Thus, the above hypothesis can be accepted as the truth.

\section{H21= sociality has a significant and positive effect on cognitive subjective norm}

Entrepreneurial intentions can be determined using an innovative cognitive style. Introduction of new opportunities enhances the creativity of employees within an organisation and hence reason their behaviours toward the fulfilment of the opportunities provided by innovation (...). Moreover, the cognitive subject norm enables people to create entrepreneur minds by connecting with prior and present experiences to generate the best performance in terms of behaviours. In relation to the study of Pejic Bach et al. (2016), the above hypothesis can be accepted.

\section{H22= innovation has a significant and positive effect on cognitive subjective norm}

In entrepreneurship, the cognitive perspective aids in the analysis of distinctive beliefs, values as well as various mental processes and models related to information and knowledge assessment that relate to the information obtained from market surveys through market-orientation (Dong et al., 2020). Ganesan argued that businesses connecting with their audience through market-orientation engage highly in problem-solving decisions that create value for their audience and allow for the modification of cognitive attitudes in relation to the subjective norms.

\section{H23 = market orientation has a significant and positive effect on cognitive subjective norm}

The innovative cognitive style stimulates the emergence of new opportunities and hence encouraging creativity within employees of an organisation. The attitudes of entrepreneurs toward society and contribution to the welfare of the environment are influenced by the introduction of new opportunities. Social impact can be measured with the arrival of these new opportunities as they bring with them other effects on society. Entrepreneurs aim to seize new opportunities hence adding onto their creativity (Ham et al., 2015). As a result, the above hypothesis is true, in that there is a significant relationship between the emergence of new opportunities and cognitive subject norm.

H24= identifying new opportunities has a significant and positive effect on cognitive subjective norm

\subsubsection{Perceived Behavioural Control}

Behavioural intention is determined by perceived behavioural control (Kiriakidis, 2017). Perceived behavioural control has been defined by Hardin-Fanning and Ricks (2017) as the 


\section{Macrothink}

International Journal of Management Innovation Systems ISSN 1943-1384

difficulty of engaging in certain behaviours. A line of comparison is drawn between the theory of planned behaviour and the theory of reasoned action by perceived behavioural control. Change in employee intention and actual behaviour within an organisation is dependent on changes in perceived behavioural control (2019). Organisations that have adequate resources tend to influence the performance of employee behaviour and generate within them, the ability to manage barriers to behaviours. According to the theory of reasoned action, individuals have a greater tendency to control their behaviourswhen they perceive fewer obstacles in their intention to perform certain behaviours (Hagger, 2019). Often, the daily environment has an everlasting effect on the intention to change behaviours, in that even if individuals intend to modify their attitudes according to requirements of the situation, the environments may not be conducive to stimulate the needed change ( $\mathrm{Fu}, 2019)$.

The study of Kiriakidis (2017) stated that perceived behavioural control is a strong determinant of behavioural intention. Employee intentions tend to change with change in perceived behavioural control. According to humanism, as people engage within the social groups that they create, the urge to behave accordingly increases. In that way, individuals modify their behaviours and attitudes to suit the situation hence accepting the above hypothesis.

\section{H25= sociality has a significant and positive effect on perceived behaviour control}

Hagger (2019) defined perceived behavioural control as the difficulty to perform a particular behaviour. According to the theory of Reasoned Action, individuals demand adequate resources to demonstrate positive attitudes toward the social cause of businesses (Hardin-Fanning \& Ricks, 2017). With innovation, businesses develop more than enough resources for their employees hence leading to the acceptance of the above hypothesis.

\section{H26= innovation has a significant and positive effect on perceived behaviour control}

Customer needs and wants are of key importance to the strategy formulation of organisations ( $\mathrm{Fu}, 2019)$. Organisations that have adequate resources to cater to all the demands of their audience create positive attitudes within the employees and hence they do not face massive challenges in controlling their negative behaviours.

\section{H27 = market orientation has a significant and positive effect on perceived behaviour control}

The above hypothesis does not have enough existing literature to support it and so this research has chosen it as one of the points of research. Concerning the theory of Reasoned Action and Planned Behaviour, intentions of an individual represent their motivations (Cristea \& Gheorghiu, 2016). the emergence of new opportunities enhances the abilities of people to perform a certain behaviour as a variety of skills are needed in new settings within an organisation. This theoretical implication supports the above hypothesis.

H28= identifying new opportunities has a significant and positive effect on perceived behaviour control 


\section{MInstitute Macrothink $^{\text {Int }}$}

2.3 Theoretical Model and Framework

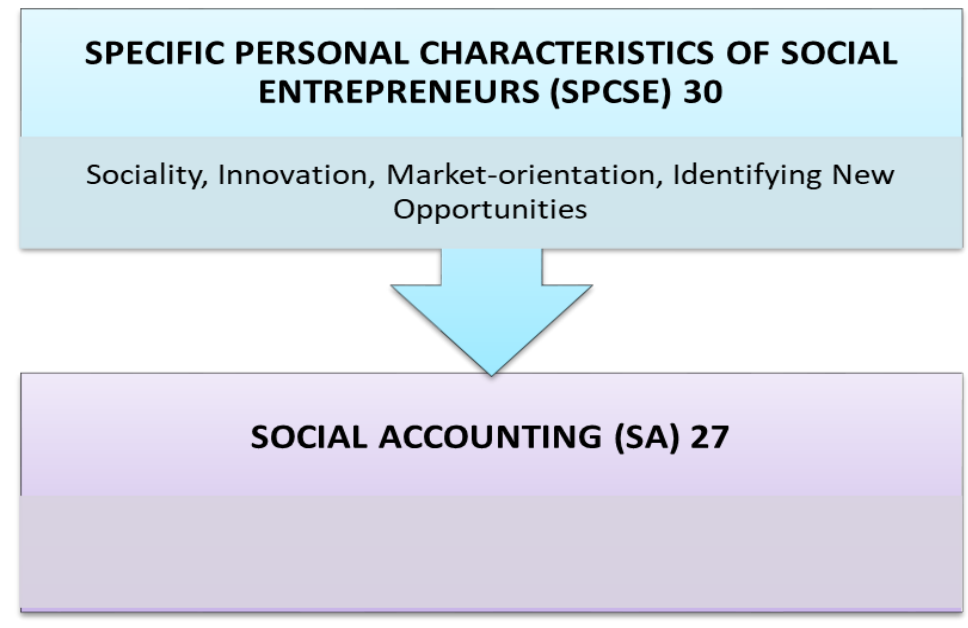

Figure 2. Model depicting the relationship amongst Specific Personal Characteristics of Social Entrepreneurs (SPCSE), Social Entrepreneurship Organizing (SEO), Social Accounting (SA) and Total Social Impact (TSI)

Source: Author.

The model depicts how the presence of social entrepreneurial traits can lead to socially-responsible organisations. When companies carefully attract, recruit and train employees who display higher levels of sociality, innovation and market-orientation, they can contribute more effectively to the betterment of society as well as the preservation of the environment.

As the first level in the model illustrates, the four dimensions of social entrepreneurship (sociality, innovation and market-orientation) help establish a culture of the entrepreneurial drive at an organisation. The workers and employees have a greater disposition towards serving the society and taking care of social interests while performing their duties and responsibilities towards the organisation.

In the second level, the seven dimensions of social accounting (pragmatic internal attitude, moral internal attitude, cognitive internal attitude, pragmatic subjective norm, moral subjective norm, cognitive subjective norm and perceived behavioural control) address how organisations tackle both their financial and social issues.

If organisations deliberately foster a company culture where social entrepreneurial traits are valued, encouraged and supported through the hiring process, top managerial commitment and regular employee education and training, then employees will display a higher level of social entrepreneurial initiative in all their undertakings.

The element of SPCSE helps bring to light the specific personality traits of employees sociality, innovation and market-orientation - that make them more responsive to social problems and opportunities. On the other hand, identification of new opportunities, 


\section{1) Macrothink}

International Journal of Management Innovation Systems

ISSN 1943-1384

collaborative leadership, teamwork and self-motivation serve as the dimensions of SEO. Similarly, Social Accounting (measured by pragmatic internal attitude, moral internal attitude, cognitive internal attitude, pragmatic subjective norm, moral subjective norm, cognitive subjective norm and perceived behavioural control) is included as one of the organisation-wide measures that take into account the diverse interests of various stakeholders for financial reporting purposes.

\section{Methodology}

\subsection{Sampling}

A sample size of $306(\mathrm{~N}=306)$ was used in the study. The 306 respondents were recruited from 75 different organisations. There were 4 employee respondents from 72 organisations each while the remaining 3 organisations had 6 employee respondents. The employee respondents were working as decision-makers within their respective firms. Close-ended questionnaires were distributed among all the respondents and they were investigated on their characteristics and how these characteristics influence social accounting in organisations.

Below is a table showing the name of the firms as well as the number of employees surveyed in each firm:

\begin{tabular}{ll}
\hline Firm Name & No. of employees surveyed \\
\hline AA ENGINEERING SERVICES & $\mathbf{4}$ \\
ABBOT LABORATORIES & 4 \\
ACF ANIMAL RESCUE & 4 \\
Al Hujjat Welfare organisation & 4 \\
Al-mustafa welfare & 4 \\
AMAAN FOUNDATION & 4 \\
ARCH CON CORPORATION & 3 \\
ARCHOMA PAKISTAN & 3 \\
ARK ASSOCIATES & 3 \\
Arthur Lawrence & 4 \\
Artistic Fabric and Garment Industries & 5 \\
BAHRIA FOUNDATION & 3 \\
BERGER PAINTS PAKISTAN LTD & 4 \\
Bykea Technologies Pvt Ltd & 3 \\
COCACOLA PAKISTAN & 4 \\
Dawlence Pakistan & 4 \\
Deewan cement & 5 \\
Delhi Foods & 4 \\
DG Cement & 4 \\
EDHI FOUNDATION & 4 \\
EFU LIFE INSURANCE & 3 \\
ENGLISH BISCUITS & 4 \\
\hline
\end{tabular}


EOBI HOUSE 2021, Vol. 6, No. 1

FaujiFurtilizer (FFC) 4

FOODPANDA 4

FOOD SAVERS 4

Freesia foods 4

Getz pharma $\quad 3$

Gul Ahmed Textile Mills Ltd. $\quad 4$

Habib Bank Limited 4

IDEAL ASSOCIATES 4

Jafria disaster cell (JDC) $\quad 4$

JAN INTERNATIONAL 4

JUBILEE LIFE INSURANCE 4

karachi electric $\quad 2$

KARACHI WELFARE TRUST 4

KINGS APPAREL 4

KHIDMAT KHALQ FOUNDATION 3

KPMG TaseerHadi\& Co. 3

Leopards Courier Service $\quad 4$

liberty mills limited 4

LUCKY TEXTILE MILLS 3

Martin dow 4

Master Group of companies 3

Matco Foods Limited 4

MSF 4

NATIONAL SECURITY PRINTING CORPRATION 4

NBP 4

NESTLE PAKISTAN $\quad 4$

NOVARTIS 4

P \& M PAKISTAN LTD 5

PEPSI \& CO 4

PIA 4

PAKISTAN SECURITY PRINTING CORPORATION 3

PAKISTAN STATE OIL 4

ROOTS MILLENIUM 3

Sadqa e jaria 3

SECURITY PAPERS LTD 4

SICPA 4

Smart technologies $\quad 4$

Soorty enterprises $\quad 4$

STATELIFE INSURANCE 4

Sui Southern Gas Company Limited 5

SUPARCO 4

Team NCC 4 
The Citizens Foundation 3

TRADE MASTERS 4

TREET CORPORATION LTD 4

UBL bank 3

Undp $\quad 3$

USAID 4

WHO 4

WORKERS FOUNDATION SCHOOL

Young's Food 4

YOUNUS MILLS 4

ZONG 3

\subsection{Instrument}

The first questionnaire is aimed at the employees working in different capacities in organisations. They can be both managerial and non-managerial staff members. The questionnaire is divided into 2 main sections 1. SPCSE which are further categorized into 4 smaller sections: A) Innovation B) Sociality C) Market-orientation D) Identifying New Opportunities. The second Section targets Social Accounting initiatives, which are further categorized into 7 different sections, each having a set of questions. The questions of the survey were adapted from the research conducted by Stevenson and Sundberg (2014). Each variable was measured using a four-point Likert Scale.

\subsection{Demographic Profile of the Respondents}

Descriptive Statistics

\begin{tabular}{|l|r|r|r|r|r|}
\hline & \multicolumn{1}{|c|}{ N } & Minimum & Maximum & Mean & Std. Deviation \\
\hline Gender & 306 & 1 & 2 & 1.46 & .499 \\
Age & 306 & 1 & 3 & 2.05 & .736 \\
Education & 306 & 1 & 2 & 1.53 & .500 \\
Valid N (listwise) & 306 & & & & \\
\hline
\end{tabular}

As seen in the table above, the standard deviation for gender is 0.499 with a mean of 1.46 . This means that majority of the respondents were male. Furthermore, the age variable had a standard deviation of 0.736 and education has a standard deviation of 0.500 .

Statistics

\begin{tabular}{|ll|r|r|r|}
\hline & & Gender & Age & Education \\
\hline N & Valid & 306 & 306 & 306 \\
& Missing & 0 & 0 & 0 \\
\hline
\end{tabular}




\begin{tabular}{|ll|r|r|r|r|}
\hline & & Frequency & Percent & Valid Percent & Cumulative Percent \\
\hline Valid & Male & 166 & 54.2 & 54.2 & 54.2 \\
& Female & 140 & 45.8 & 45.8 & 100.0 \\
& Total & 306 & 100.0 & 100.0 & \\
\hline
\end{tabular}

The Frequency table of gender shows that majority of the respondents are males with a percentage of 54.2 and a frequency of 166 respondents. Out of the 306 participants, 140 of them were females with a percentage of 45.8 .

\begin{tabular}{|rl|r|r|r|r|}
\hline \multicolumn{7}{|c|}{ Age } \\
\hline Valid & 24-34 years & Frequency & Percent & Valid Percent & Cumulative Percent \\
& 76 & 24.8 & 24.8 & 24.8 \\
& 35-40 years & 140 & 45.8 & 45.8 & 70.6 \\
41-50 years & 90 & 29.4 & 29.4 & 100.0 \\
& Total & 306 & 100.0 & 100.0 & \\
\hline
\end{tabular}

Most of the survey respondents were in the 35 to 40 years age bracket with a percentage of 45.8 and frequency of 140 . There were only 76 respondents aged 24-34 that participated in the survey. Moreover, 90 participants were aged 41 to 50 years.

\section{Education}

\begin{tabular}{|ll|r|r|r|r|}
\hline & Frequency & Percent & Valid Percent & Cumulative Percent \\
\hline Valid & Masters & 145 & 47.4 & 47.4 & 47.4 \\
& Bachelors & 161 & 52.6 & 52.6 & 100.0 \\
Total & 306 & 100.0 & 100.0 & \\
\hline
\end{tabular}

As seen in the table of education demographics, the total number of respondents that held a masters degree is 145 while 161 respondents had only a bachelors degree. The total percentage of the respondents that had a bachelors degree only is 52.6. 


\subsection{Descriptive Statistic}

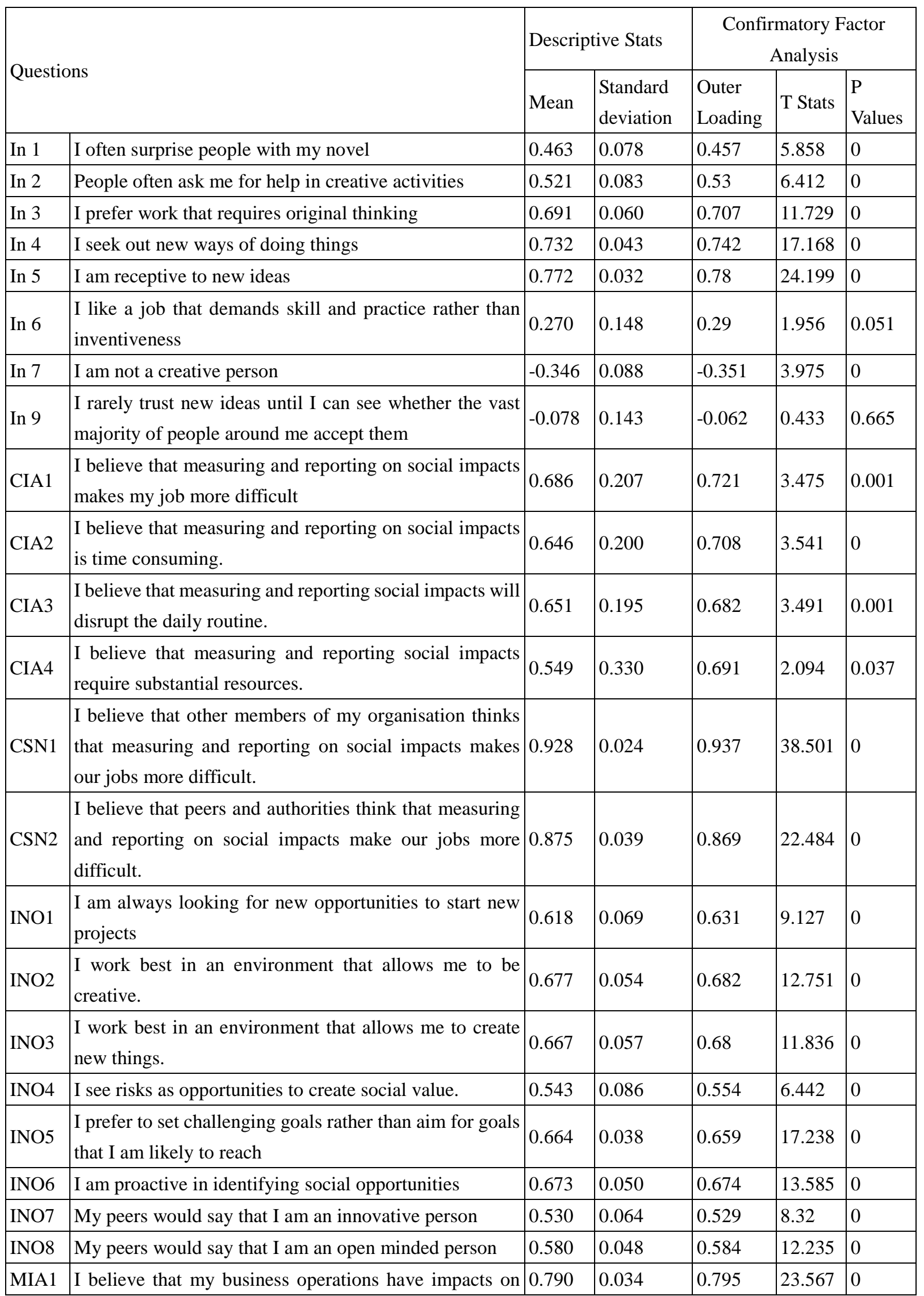




\begin{tabular}{|c|c|c|c|c|c|c|}
\hline & society & & & & & \\
\hline MIA2 & $\begin{array}{l}\text { I believe that taking responsibility for my businesses } \\
\text { social impacts is the right thing to do }\end{array}$ & 0.839 & 0.032 & 0.842 & 26.452 & 0 \\
\hline MIA3 & $\begin{array}{l}\text { I believe that measuring and reporting on social impacts } \\
\text { is the right thing to do }\end{array}$ & 0.736 & 0.049 & 0.738 & 15.129 & 0 \\
\hline MO1 & I belive in selling goods and services for a profit & 0.570 & 0.198 & 0.612 & 3.088 & 0.002 \\
\hline MO2 & I believe in maximizing financial wealth & 0.656 & 0.202 & 0.708 & 3.511 & 0 \\
\hline MO3 & I believe in maximizing the wealth of investors & 0.677 & 0.200 & 0.74 & 3.695 & 0 \\
\hline MO4 & I believe in company survival through profits & 0.635 & 0.178 & 0.692 & 3.89 & 0 \\
\hline MO5 & Making profits is a means to achieve a social goal & 0.286 & 0.173 & 0.316 & 1.831 & 0.068 \\
\hline MO6 & $\begin{array}{l}\text { I believe that a company should engage in both business } \\
\text { and social goals in communities and/or markets }\end{array}$ & 0.605 & 0.345 & 0.708 & 2.056 & 0.04 \\
\hline MSN1 & $\begin{array}{l}\text { I believe that other members of my organisation think } \\
\text { that business operations have impacts on society. }\end{array}$ & 0.641 & 0.057 & 0.649 & 11.473 & 0 \\
\hline MSN2 & $\begin{array}{l}\text { I believe that peers and authorities think that business } \\
\text { operations have impacts on society. }\end{array}$ & 0.668 & 0.058 & 0.674 & 11.591 & 0 \\
\hline MSN3 & $\begin{array}{l}\text { I believe that other members of my organisation think } \\
\text { that taking responsibility over a businesses social } \\
\text { impacts is the right thing to do. }\end{array}$ & 0.713 & 0.043 & 0.712 & 16.478 & 0 \\
\hline MSN4 & $\begin{array}{l}\text { I believe that peers and authorities think that taking } \\
\text { responsibility over a business's social impacts is the right } \\
\text { thing to do. }\end{array}$ & 0.801 & 0.031 & 0.803 & 25.561 & 0 \\
\hline MSN5 & $\begin{array}{l}\text { I believe that other members of my organisation think } \\
\text { that measuring and reporting on social impacts is the } \\
\text { right thing to do. }\end{array}$ & 0.740 & 0.049 & 0.745 & 15.211 & 0 \\
\hline MSN6 & $\begin{array}{l}\text { I believe that peers and authorities think that measuring } \\
\text { and reporting on social impacts is the right thing to do. }\end{array}$ & 0.843 & 0.024 & 0.846 & 35.339 & 0 \\
\hline PBC1 & $\begin{array}{l}\text { I believe that I have the ability to reduce the negative } \\
\text { social impacts caused by my organisation. }\end{array}$ & 0.603 & 0.057 & 0.604 & 10.619 & 0 \\
\hline PBC2 & $\begin{array}{l}\text { I believe that my actions as a manager can make a } \\
\text { difference in society. }\end{array}$ & 0.691 & 0.050 & 0.697 & 13.837 & 0 \\
\hline PBC3 & $\begin{array}{l}\text { I believe that I have the time to measure and report on } \\
\text { social impacts. }\end{array}$ & 0.655 & 0.051 & 0.657 & 12.879 & 0 \\
\hline PBC4 & $\begin{array}{l}\text { I believe that I have the resources necessary to measure } \\
\text { and report on social impacts. }\end{array}$ & 0.759 & 0.036 & 0.757 & 20.913 & 0 \\
\hline PBC5 & $\begin{array}{l}\text { I believe that I have the knowledge and competence } \\
\text { needed to measure and report on social impacts. }\end{array}$ & 0.790 & 0.033 & 0.795 & 24.083 & 0 \\
\hline PIA1 & $\begin{array}{l}\text { I believe that measuring and reporting on social impacts } \\
\text { benefits my business }\end{array}$ & 0.740 & 0.059 & 0.746 & 12.642 & 0 \\
\hline PIA3 & $\begin{array}{l}\text { I believe that measuring and reporting on social impacts } \\
\text { improves my company's repuation and image }\end{array}$ & 0.839 & 0.037 & 0.842 & 22.672 & 0 \\
\hline PIA4 & $\begin{array}{l}\text { I believe that measuring and reporting on social impacts } \\
\text { leads to reduced costs }\end{array}$ & 0.360 & 0.138 & 0.375 & 2.722 & 0.007 \\
\hline
\end{tabular}




\begin{tabular}{|l|l|l|l|l|l|l|}
\hline PSN1 & $\begin{array}{l}\text { I believe that other members of my team think that } \\
\text { measuring and reporting on social impacts benefits our } \\
\text { business. }\end{array}$ & 0.847 & 0.049 & 0.852 & 17.304 & 0 \\
\hline PSN2 & $\begin{array}{l}\text { I believe that peers and authorities think that measuring } \\
\text { and reporting on social impacts benefits our business. }\end{array}$ & 0.910 & 0.032 & 0.91 & 28.402 & 0 \\
\hline S1 & I know what is expected of me in different situations & 0.512 & 0.083 & 0.51 & 6.164 & 0 \\
\hline S2 & I take a focused stand on social issues & 0.765 & 0.030 & 0.765 & 25.164 & 0 \\
\hline S3 & I am strongly committed to a social vision & 0.751 & 0.046 & 0.758 & 16.5 & 0 \\
\hline S5 & I have a strong motivation to defend a social need & 0.780 & 0.030 & 0.782 & 25.936 & 0 \\
\hline S6 & I am determined to be an agent of social change & 0.678 & 0.056 & 0.683 & 12.179 & 0 \\
\hline
\end{tabular}

As seen in the table above, CSN1 has the highest t-value of 38.501. This implies that many participants agreed to the statement that "I believe that other members of my organisation thinks that measuring and reporting on social impact makes our jobs more difficult". Moreover, the respondents of the survey demonstrated positive influence of sociality as seen by the t-value of S5, 25.936. To add on, the standard deviation of all the statements is quite low implying that there is little difference between the sample mean and the original mean of the values given by the respondents. In 7 and In9 have a negative mean, -0.346 and -0.078 respectively, as seen in the descriptive statistics table above. With reference to the table above, In9 has a $t$-value of 0.433 at $p>0.05$ indicating that the statement "I rarely trust new ideas until I can see whether the vast majority of people around me accept them" can be accepted to be true and agreed upon by many participants. As seen from the table above, the respondents of the survey are encouraged by sociality, innovation as well as perceived behavioural control in the decision-making related to social accounting practices.

\subsection{Structural Modeling}

We used SEM to validate research theory and testing was done using Smart PLS programming. In addition, tests were conducted to evaluate abnormal and direct impacts on multiple nodes. The use of the auxiliary state model (SEM) has been seen as an outstanding system that has been used in various models and methods of relapse (Barron \& Kenny, 1986). It is used to assess the underlying relationship between exogenous and endogenous factors. It includes factorial research and multivariate survey. In addition, the relapse condition seeks to uncover each assembly to assess the relationship of circumstances and logical outcomes, while a set of components in a causal model can show their circumstances and logical outcomes at a specific time. Moreover, using this model ensures that a bootstrap method is applied that is considered reasonable for both small and large examples and does not require any backtracking (Hayes, 2013). To test all immediate and reverse effects, a procedure known as bootstrapping was performed (Shrout \& Bolger, 2002).

\section{Measurement of Outer Model}

The purpose of the conformance relationship in the assessment model is to learn about the continued quality and legitimacy of the instrument, and to test its reliability and legitimacy. 


\section{Macrothink}

International Journal of Management Innovation Systems

ISSN 1943-1384

We run a test of simultaneous legitimacy and discriminant legitimacy in programming called Smart PLS.

\section{Composite Reliability}

Reliability implies the stability of the survey results. For comparable objective groups, at whatever point the examiner reuses the survey, he will give a comparative result. It exhibits unrivaled stability and repeatability. The most important measure of the quality of fidelity is to keep the research shame out of the way. Thus, it will usually be improved by testing the methodology and training of interest, and completed using different research and evaluation strategies or different analysts. This further brings together the reliability and credibility of the investigation.

The quality of the instruments was judged by overall reliability. All qualities were above the commonly used border, such as 0.70 . This is a recognized range for assessing reliability. Evaluation of unshakable quality should be possible in terms of the level of stability that depends on various factors (Hair, 2010). Below is a table of impeccable quality of composites.

\begin{tabular}{|l|c|}
\hline \multicolumn{1}{|c|}{ Variables } & Composite Reliability \\
\hline cognitive internal attitude & 0.794 \\
\hline cognitive subjective norm & 0.899 \\
\hline identify new opportunities & 0.837 \\
\hline innovative market & 0.683 \\
\hline market orientation & 0.803 \\
\hline moral internal attitude & 0.835 \\
\hline moral subjective norm & 0.879 \\
\hline perceived behavioural control & 0.830 \\
\hline pragmatic internal attitude & 0.708 \\
\hline pragmatic subjective norm & 0.875 \\
\hline sociality & 0.830 \\
\hline
\end{tabular}

\section{Factor loadings significant}

Graphical table of measurements with additional links to loads used in the CFA study. A throw with a throw of 0.5 is considered an important factor for a throw, although a throw below 0.5 is considered less appropriate for elimination from the table.

\section{Convergent Validity}

Consolidated legitimacy is a degree of understanding in at least two proportions of comparable development (Carmines \& Zeller, 1979). Collaborative legitimacy was assessed by examining the changes identified for each factor (Fornell \& Larcker, 1981). Introducing Fornell and Larker (1981), if the difference between the values is more noticeable than 0.5 , this stage establishes simultaneous legitimacy and concludes that loads are acceptable, but 
less than 0.5 is called less powerful for investigation.

Following table displays the result.

\begin{tabular}{lllll}
\hline & $\begin{array}{l}\text { Cronbach's } \\
\text { Alpha }\end{array}$ & rho_A & $\begin{array}{l}\text { Composite } \\
\text { Reliability }\end{array}$ & $\begin{array}{l}\text { Average Variance } \\
\text { Extracted (AVE) }\end{array}$ \\
\hline cognitive internal attitude & 0.663 & 0.663 & 0.794 & 0.491 \\
cognitive subjective norm & 0.781 & 0.850 & 0.899 & 0.816 \\
identify new opportunities & 0.778 & 0.785 & 0.837 & 0.393 \\
innovative market & 0.518 & 0.716 & 0.683 & 0.337 \\
market orientation & 0.717 & 0.762 & 0.803 & 0.417 \\
moral internal attitude & 0.706 & 0.717 & 0.835 & 0.629 \\
moral subjective norm & 0.835 & 0.856 & 0.879 & 0.550 \\
perceived behavioural control & 0.743 & 0.746 & 0.830 & 0.497 \\
pragmatic internal attitude & 0.450 & 0.536 & 0.708 & 0.469 \\
pragmatic subjective norm & 0.718 & 0.745 & 0.875 & 0.778 \\
sociality & 0.749 & 0.781 & 0.830 & 0.500 \\
\hline
\end{tabular}

\section{Discrimant Validity:}

The standard of Fornell-Larcker (1981) has been normally used to survey the level of shared change between the dormant factors of the model.As per mainstream FornellLarcker rule (Fornell \& Larcher, 1981), you should contrast the AVE esteem and comparing relationship esteems with different factors for setting up discriminant legitimacy. In any case, for fluctuation based SEM (e.g., PLS), you are instructed to utilize square-root esteem concerning AVE to contrast and relating connection esteems with different factors (Hair et al., 2014) due to its affectability to overestimate marker/thing stacking (Hui \& Wold, 1982; Lohmöller, 1989).

\section{Fornell-Larcker Criterion}

\begin{tabular}{|l|l|l|l|l|l|l|l|l|l|l|l|}
\hline & CIA & CSN & INO & IM & MO & MIA & MSN & PBC & PIA & PSN & S \\
\hline cognitive internal attitude & 0.700 & & & & & & & & & & \\
\hline cognitive subjective norm & 0.493 & 0.904 & & & & & & & & & \\
\hline identify new opportunities & 0.017 & -0.083 & 0.627 & & & & & & & & \\
\hline innovative market & 0.041 & -0.062 & 0.573 & 0.580 & & & & & & & \\
\hline market orientation & 0.261 & 0.233 & 0.372 & 0.353 & 0.646 & & & & & & \\
\hline moral internal attitude & 0.012 & -0.036 & 0.488 & 0.414 & 0.239 & 0.793 & & & & & \\
\hline moral subjective norm & -0.055 & -0.103 & 0.378 & 0.343 & 0.180 & 0.306 & 0.741 & & & & \\
\hline perceived behavioural control & -0.010 & -0.071 & 0.495 & 0.386 & 0.213 & 0.285 & 0.472 & 0.705 & & & \\
\hline pragmatic internal attitude & 0.114 & 0.095 & 0.440 & 0.460 & 0.286 & 0.568 & 0.295 & 0.343 & 0.685 & & \\
\hline pragmatic subjective norm & 0.005 & -0.092 & 0.312 & 0.258 & 0.195 & 0.366 & 0.512 & 0.409 & 0.326 & 0.882 & \\
\hline sociality & -0.011 & -0.152 & 0.624 & 0.516 & 0.286 & 0.436 & 0.292 & 0.412 & 0.386 & 0.321 & 0.707 \\
\hline
\end{tabular}




\section{MIN Macrothink \\ International Journal of Management Innovation Systems \\ ISSN 1943-1384 \\ 2021, Vol. 6, No. 1}

\section{Model Fit Measures:}

The model fit assessments including the intentional examination of both brought down model nearly as the assessed model. The SRMR is portrayed as the differentiation between the watched relationship and the model proposed association framework. Thusly, it grants assessing the typical size of the mistakes among watched and expected associations as a level out the extent of (model) fit. Estimations of both soaked and assessed model are the piece of model fit as appeared in table A.

Table A:

\begin{tabular}{lll}
\hline & Saturated Model & Estimated Model \\
\hline SRMR & 0.085 & 0.097 \\
d_ULS & 9.611 & 12.383 \\
d_G & 2.349 & 2.550 \\
Chi-Square & 3776.694 & 4011.765 \\
NFI & 0.470 & 0.437 \\
\hline
\end{tabular}

\subsection{The Structural Model (Inner Model) and Hypotheses Testing}

The structural model helps to understand and analyses the complex relations of the variables, Marko Sarstedt and Jun-HwaCheah (2019). The structural model was also tested and run on the SmartPLS 3.2.3 (Ringle, Wende, \& Becker, 2015). The structural model was run through bootstrapping (Efronand, 1968, Haenlien \& Kaplan, 2004). The snapshot of the result after running the test is attached below along with the interpretation of the results.

In PLS-SEM, bootstrapping is one of the key strides, which gives the data of constancy of factor guesstimate.Sub-tests are drawn everywhere from the first example including substitution, in this process (Hair, Matthews, Matthews, \& Sarstedt, 2017). Bootstrapping provides the information of stability of the coefficient estimate. In this process, a large number of sub-samples are drawn from the original sample with replacement (Hair et al. 2016). After running the bootstrap routine, SmartPLS shows the t-values for structural model estimates derived from the bootstrapping procedure. The results of path coefficients for all the hypothesis are shown in the following table. The t-value greater than $1.96(\mathrm{p}<.005)$ shows that the relationship is significant at 95\% confidence level $(\alpha=0.05)$. Paths showing whether the relationship between measured and latent variables are significant or not. The path diagram showed in figure 3. The data has been run on smart pls with algorithm \& bootstrapping to determine the results either to accept or reject the projected hypothesis. This product figures standard outcomes appraisal measures (e.g., for the reflective and formative measurement models, the structural model, and the goodness of fit). 


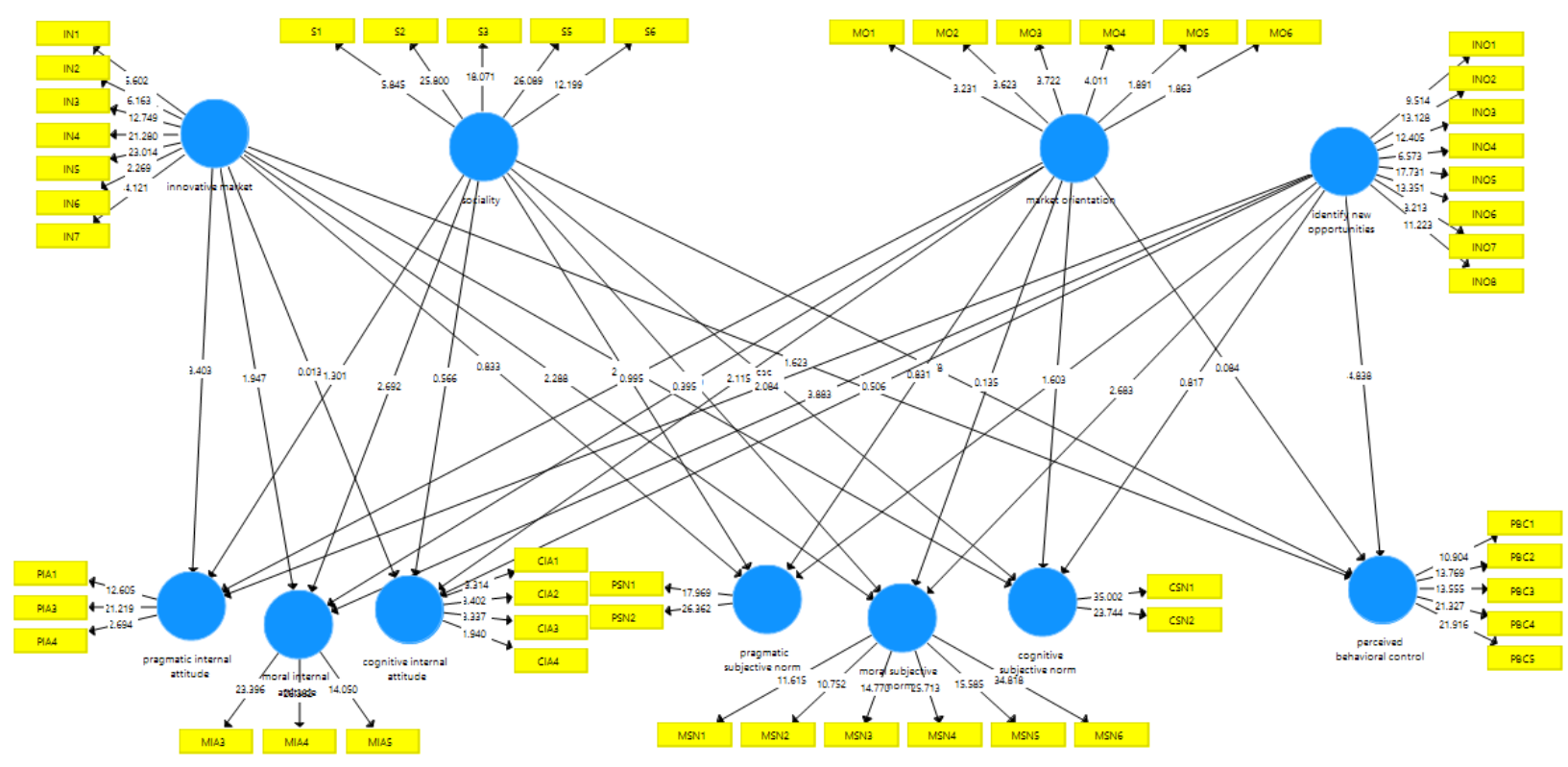

Figure 3. After running the bootstrap consequences of way coefficients for all theory appear in table $\mathrm{B}$. The noteworthiness can be appeared by the assistance of $\mathrm{T}$ and $\mathrm{P}$ esteems

Note. I.e is $\mathrm{T}>1.96(\mathrm{p}<0.05)$ significant whereas $\mathrm{T}<1.96(\mathrm{p}>0.05)$ insignificant.

Path Coefficients for All the Hypothesis

\begin{tabular}{|l|l|l|l|l|l|}
\hline \multicolumn{2}{|c|}{ HYPOTHESIS } & Est. & T Stats & P Values & Decision \\
\hline H1 & sociality -> pragmatic internal attitude & 0.105 & 1.301 & $\mathbf{0 . 1 9 4}$ & Reject \\
\hline H2 & innovative market -> pragmatic internal attitude & 0.266 & 3.403 & $\mathbf{0 . 0 0 1}$ & Accept \\
\hline H3 & market orientation -> pragmatic internal attitude & 0.092 & 0.995 & $\mathbf{0 . 3 2 0}$ & Reject \\
\hline H4 & identify new opportunities -> pragmatic internal attitude & 0.188 & 2.084 & $\mathbf{0 . 0 3 8}$ & Accept \\
\hline H5 & sociality -> moral internal attitude & 0.172 & 2.692 & $\mathbf{0 . 0 0 7}$ & Accept \\
\hline H6 & innovative market -> moral internal attitude & 0.152 & 1.947 & $\mathbf{0 . 0 5 2}$ & Accept \\
\hline H7 & market orientation -> moral internal attitude & 0.031 & 0.395 & $\mathbf{0 . 6 9 3}$ & Reject \\
\hline H8 & identify new opportunities -> moral internal attitude & 0.282 & 3.883 & $\mathbf{0 . 0 0 0}$ & Accept \\
\hline H9 & sociality -> cognitive internal attitude & -0.061 & 0.566 & $\mathbf{0 . 5 7 2}$ & Reject \\
\hline H10 & innovative market -> cognitive internal attitude & -0.001 & 0.013 & $\mathbf{0 . 9 8 9}$ & Reject \\
\hline H11 & market orientation -> cognitive internal attitude & 0.299 & 2.115 & $\mathbf{0 . 0 3 5}$ & Accept \\
\hline H12 & identify new opportunities -> cognitive internal attitude & -0.056 & 0.506 & $\mathbf{0 . 6 1 3}$ & Reject \\
\hline H13 & sociality -> pragmatic subjective norm & 0.185 & 2.432 & $\mathbf{0 . 0 1 5}$ & Accept \\
\hline H14 & innovative market -> pragmatic subjective norm & 0.060 & 0.833 & $\mathbf{0 . 4 0 5}$ & Reject \\
\hline H15 & market orientation -> pragmatic subjective norm & 0.071 & 0.831 & $\mathbf{0 . 4 0 7}$ & Reject \\
\hline H16 & identify new opportunities -> pragmatic subjective norm & 0.136 & 1.603 & $\mathbf{0 . 1 1 0}$ & Reject \\
\hline H17 & sociality -> moral subjective norm & 0.046 & 0.530 & $\mathbf{0 . 5 9 7}$ & Reject \\
\hline H18 & innovative market -> moral subjective norm & 0.175 & 2.288 & $\mathbf{0 . 0 2 3}$ & Accept \\
\hline H19 & market orientation -> moral subjective norm & 0.015 & 0.135 & $\mathbf{0 . 8 9 3}$ & Reject \\
\hline
\end{tabular}




\begin{tabular}{|l|l|l|l|l|l|}
\hline H20 & identify new opportunities -> moral subjective norm & 0.244 & 2.683 & $\mathbf{0 . 0 0 8}$ & Accept \\
\hline H21 & sociality -> cognitive subjective norm & -0.181 & 2.535 & $\mathbf{0 . 0 1 2}$ & Accept \\
\hline H22 & innovative market -> cognitive subjective norm & -0.046 & 0.586 & $\mathbf{0 . 5 5 8}$ & Reject \\
\hline H23 & market orientation -> cognitive subjective norm & 0.325 & 2.373 & $\mathbf{0 . 0 1 8}$ & Accept \\
\hline H24 & identify new opportunities -> cognitive subjective norm & -0.065 & 0.817 & $\mathbf{0 . 4 1 4}$ & Reject \\
\hline H25 & sociality -> perceived behavioural control & 0.138 & 1.878 & $\mathbf{0 . 0 6 1}$ & Accept \\
\hline H26 & innovative market -> perceived behavioural control & 0.120 & 1.623 & $\mathbf{0 . 1 0 5}$ & Reject \\
\hline H27 & market orientation -> perceived behavioural control & 0.006 & 0.084 & $\mathbf{0 . 9 3 3}$ & Reject \\
\hline H28 & $\begin{array}{l}\text { identify new opportunities -> perceived behavioural } \\
\text { control }\end{array}$ & 0.338 & 4.838 & $\mathbf{0 . 0 0 0}$ & Accept \\
\hline
\end{tabular}

As seen in the table above, H1, H3, H7, H9, H10, H12, H14, H15, H16, H17, H19, H22, H24, $\mathrm{H} 26$ and $\mathrm{H} 27$ have been rejected by the study. Moreover, H2, H4, H5, H6, H8, H11, H13, $\mathrm{H} 18, \mathrm{H} 20, \mathrm{H} 21, \mathrm{H} 23, \mathrm{H} 25$ and $\mathrm{H} 28$ have been accepted. Concerning the values in the table, there is no significant relationship between sociality and pragmatic internal attitude as well as market-orientation and pragmatic internal attitude. H2 and H6 have p values of 0.001 and 0.052 respectively. These values demonstrate a positive significant impact of innovativeness on pragmatic and moral internal attitude and moral subjective norm that has a p-value of 0.023. sociality has a positive significant impact on moral internal attitude, pragmatic subjective norm, moral subjective norm and perceived behavioural control as seen in the hypothesis table above. However, there is a negative relationship between sociality and cognitive internal attitude with a p-value of 0.572 .

With reference to table $\mathrm{B}$, there is a significant positive impact demonstrated on cognitive internal attitude and cognitive subjective norm by market orientation. Similarly, individual new opportunities demonstrate a positive impact on perceived behavioural control presenting a p-value of 0.000. Cognitive internal attitude and identifying new opportunities have a negative significant relationship as displayed in table B.

\section{Discussion}

The findings of this study demonstrate that no respondent associated a negative attitude toward social accounting, in that they were not completely negative but also not completely positive. Referring to observations made by the researchers, some respondents did not show a full positive attitude toward social accounting as it was less evident in actions. In line with the study of Cassells and Lewis (2011), actions and attitudes don't need to reflect each other in the business context. There was the presence of uncertainty due to the gap between the displayed and measured attitudes and the performed actions. In order to fill this gap, the respondents needed to demonstrate an entirely positive attitude toward social accounting.

Thomas and Lamm (2012) established a framework to determine the attitude of individuals towards the behaviour. According to this framework, there are different cornerstones of these attitudes which consist of the dimensions of moralism, cognition and pragmatism. While referring to the findings of this study, it can be said that the moral dimension of attitudes is 
the prime dimension to reflect a clear positive attitude toward social accounting. This can be said by looking at the acceptance of the hypotheses, H5, H6 and H8. Sociality, innovative market as well as the identification of new opportunities have a significant positive impact on moral internal attitude as seen by the t-values of 2.692, 1.947 and 3.883 respectively. The t-values are greater than $1.96(\mathrm{p}<0.005)$ demonstrating a significant relationship at $95 \%$ confidence level.

The study of Stevenson and Sundberg (2014) went ahead to conduct interviews investigating respondents on their views about social accounting and its need to promote sustainability. As per the findings of their study, some participants agree to the importance of social accounting for improved sustainability performance of an organisation while some believe that sustainability does not necessarily need social accounting externally as stated in the study of Pederson et al. (2013). The findings of this study show that four respondents are least interested in engaging in social accounting procedures stating that what they do does not impact the social accounting process within the organisation.

It cannot be ignored that the study of Stevenson and Sundberg (2014) and Pedersen et al. (2013) is based on evaluation of small-medium enterprise (SME) managers. However, in this study, the researcher did not specify whether the firms recruited into the survey were small-medium or large enterprises and hence it can be said that the findings of this study relatively differ from those of Stevenson and Sundberg (2014) and Pederson et al. (2013).

Although the results of this study can be applied to and support previous research findings, they differ highly in context as this study employed personal characteristics of social entrepreneurship and examined the effects of these characteristics on social accounting within different organisations in Pakistan. Moreover, the study of Stevenson and Sundberg (2014) was based in Sweden. Sweden and Pakistan differ in growth and economical terms as the latter is a developing country while the former is a developed country (Hertzberg et al., 2020).

Following the moral dimension, the pragmatic dimension shows more positivity than the cognitive dimension of attitudes. Two out of the four hypotheses associated with pragmatic internal attitude have been accepted. As per the findings of this study, innovativeness has a positive significant impact on the pragmatic internal attitude of employees represented by a t-value of 3.403. During the survey, many respondents identified benefits stemming from social accounting. Some of these benefits were compatible with the findings of previous researches.

Marketing purposes were the most frequent benefits stated by the majority of the respondents. These were in line with the study of Barraket and Yousefpour (2013). Their study also emphasizes marketing benefits from social accounting leading to sustainable performance within an organisation. Furthermore, as mentioned by the respondents of this study, there is a possibility of new idea discovery and internal problem-solving methods relating to the improvement in pragmatic internal attitude. To add on, some participants stated that evaluation of business operations through social accounting leads to improved performance as well as identification of weaknesses. Porter and Kramer (2011) have argued that social 
accounting can result in financial benefits for companies that engage in the practice. This is a concept that was not highlighted by any of the respondents in this study.

The cognitive dimension of attitude demonstrated a negative collective estimated value. The impact of sociality on cognitive internal attitude demonstrated an estimated value of -0.061 with a t-value of 0.566 . Thus, sociality impacted cognitive internal attitude negatively. Additionally, innovative market and identifying new opportunities also had a negative impact on cognitive internal attitude with estimated values of -0.001 and -0.056 respectively. The t-values of $\mathrm{H} 10$ and $\mathrm{H} 12$ are 0.013 and 0.506 respectively. About the survey responses obtained, the respondents noted that conducting social accounting is a very time-consuming process and requires intensive resources that sometimes lead to no extrinsic rewards which might result in amplified motivation for the employees working within an organisation. The findings of the study of Barraket and Yousefpour (2013) and Pedersen et al. (2013) suggest that time restraints, challenging documentation and contending work commitments are some of the difficulties perceived by managers within an organisation has to engage in social accounting practices. The findings of Barraket and Yousefpour (2013) further state that managers are ripped off their main duties giving more time to documentation for social accounting. In this study, the respondents were not interviewed but rather a survey was conducted which isolated social accounting as an individualistic approach.

Most participants believed that social accounting would add difficulty in job performance. Aside from the three dimensions of attitude, this study also looks at the dimension of perceived behavioural control which was also proposed by Thomas and Lamm (2012) in their framework model. Many respondents expressed ambiguity and vagueness regarding their abilities to comprehend the knowledge required for social accounting practices. According to the findings of this study, innovative market and market-orientation did not have any significant impact on perceived behavioural control while sociality and identifying new opportunities had a significant positive impact on perceived behavioural control.

\section{Conclusion}

In this research, the empirically test the presence of social entrepreneurship traits and test whether those traits affect the organisation-wide social accounting measures. Moreover also understand the relationship amongst specific personal characteristics of social entrepreneurs (SPCSE), social entrepreneurship organizing (SEO), social accounting (SA) and total social impact (TSI). To confirm the reliability and consistency of measuring Cronbach's alpha were used. To study the relationship bootstrapping test was used and path coefficient of the path model helps in determining the association among the variables. Results of the study show that out of 28 hypotheses 11 have significant while rest 17 have an insignificant impact on the study. This exploration study pursues to isolate the social entrepreneurship profile that highlights the specific personal characteristics of workforces working in an organisation; in addition, it endeavours to understand how the comprehensive initiatives that help today's organisations become more socially accountable.

In order to answer the main and subsidiary research questions of this study, the researchers employed survey-based research by investigating the effect of personal characteristics on the 
intention to engage in social accounting within organisations.

The social entrepreneurship profile defined four personal characteristics namely, innovation, sociality, market-orientation and identifying new opportunities. According to the findings of the study, all the four characteristics impact the social accounting initiatives in a way or the other by looking at the three attitudinal dimensions and perceived behavioural control.

Pragmatic internal attitude is positively impacted by innovativeness relating to marketing. The marketing sector witnesses innovations with every coming day due to the changes and advancements in technology. Moreover, enhanced marketing measures results in sustainable performance for organisations as well as their employees. To add on, the identification of new opportunities brings more solutions for existing problems. Decision-makers see this as an opportunity to engage in problem-solving with aid provided by the new opportunities. This is seen to bring an improvement in the pragmatic internal attitude as presented by the results of this study. On the other hand, sociality and market-orientation have a negative impact on social accounting initiatives.

The moral dimension of attitudes is the prime dimension to reflect a clear positive attitude toward social accounting. Decision-makers have predefined concepts and rules regarding what is right and wrong in their internal selves. Sociality, innovative market as well as the identification of new opportunities have a significant positive impact on moral internal attitude. While engaging with peers and colleagues, decision-makers are morally motivated to indulge in activities that are agreed upon by the majority. Social accounting brings sustainability and progress to organisations and hence employees would want to engage in such practices for growth of the business as well as personal growth.

The cognitive dimension of attitude is impacted negatively by sociality, innovative market and identifying new opportunities. There is a positive relationship between market-orientation and cognitive internal attitude. This is because decision-makers align their previous experiences and rationally build their thought process to understand the requirements of the present. The study has revealed that social accounting is seen as a time-consuming process and heavy documentation results in distraction of managers from their actual job. This further implies that new opportunities are seen as an extra burden on the organisation and hence can be ignored to first deal with the existing issues.

However, there is no evident impact of innovative market and market-orientation on perceived behavioural control. Sociality and identification of new opportunities, however, makes it easier for decision-makers to engage in a particular behaviour as per the findings of this study. Through communication within social groups, employees are motivated to perform a behaviour that leads to positive outcomes for the organisations.

According to the results generated from the survey, social accounting policies are highly dependent on the behaviours of organiation employees as well as the key decision-makers. Firms that are lagging behing in the implementation of a thorough social accounting system can therefore use the findings of this study to formulate policies that will stimulate positive socially relevant behaviour of decision-makers and/or managers within organisations to boost 
the process of social accounting. To add on, certain organisations have worked on strategies that encourage the reporting of organisational activities that not only cause harm to the society but also malign the image of the firm. In such cases, employees are often looked down by the top authorities. For this reason, the top management levels in an organisation need to motivate and encourage their employees to work toward social accounting to enhance the service quality in the direction of the society.

Nevertheless, the study findings have led to the conclusion that the perceived behavioural control (PBC) factor has had a huge impact on the behaviours of managers within firms. With reference to this, organisations can introduce training programs to understand the behaviours of certain employees and how those behaviours are seemed controllable. Besides, difficulty in job performance has been figured out as one of the hindrances in the proper implementation of social accounting practices within firms. In order to combat this situation, organisations are required to setup policies that guide the employees through eah and every step of the social accounting process. Thus, this will ease their work and also save time as they will not have to stress on the what is required of them. The study has also brought to the conclusion that strong social accounting practices and positive employee behaviour toward the concept adds to a better social performance for the company leading to unprecedented and stable growth.

\subsection{Limitations and Recommendations}

One of the main obstacles to this study was the lack of time due to which quantitative methods were used to collect information. The sample size included 307 workers from 75 different associations and does not cover the entire population of Pakistan. To break down the information, we used a convenient learning strategy that does not cover all areas of Pakistan. Moreover, due to pandemic attack, the responses are mostly taken without interaction that would create uncertainty that how much keen or interested an employee is to provide accurate data. Sample size should be increased to cover the other regions of Pakistan in order to represent the population. Test size ought to be expanded to cover different locales of Pakistan to speak to the populace. Moreover, concentrating the examination on Pakistan, the example of the investigation is probably going to be restricted with specific gatherings with comparative segment attributes.

\section{References}

Afsar, B., Al-Ghazali, B., \& Umrani, W. (2020). Corporate social responsibility, work meaningfulness, and employee engagement: The joint moderating effects of incremental moral belief and moral identity centrality. Corporate Social Responsibility and Environmental Management, 27(3), 1264-1278. https://doi.org/10.1002/csr.1882

Ajzen, I. (2005). Attitudes, Personality and Behaviour (pp. 105-123). Maidenhead: Open University Press.

Alvourd, S., Brown, L., \& Letts, C. (2004). Social entrepreneurship and societal transformation: An exploratory study. Journal of Applied Behavioural Science, 4(3), 260-282. https://doi.org/10.1177/0021886304266847 


\section{Macrothink}

International Journal of Management Innovation Systems

ISSN 1943-1384

Aman Shah, S. H., \& Mohd Ali, M. R. (2008). Entrepreneurship. Oxford FajarSdn. Bhd, Shah Alam. https://doi.org/10.1016/B978-032304853-8.50024-X

Ansell, C., \& Gash, A. (2012). Stewards, Mediators and Catalysts: Toward a Model of Collaborative Leadership. The Innovation Journal, 17(1), 1-21.

Ardichvili, A., Cardozo, R., \& Ray, S. (2003). A theory of entrepreneurial opportunity identification and development. Journal of Business Venturing, 18(1), 105-123. https://doi.org/10.1016/S0883-9026(01)00068-4

Awad, E., Dsouza, S., Kim, R., Schulz, J., Henrich, J., Shariff, A., ... \& Rahwan, I. (2018). The moral machine experiment. Nature, 563(7729), 59-64. https://doi.org/10.1038/s41586-018-0637-6

Barraket, J., \& Yousefpour, N. (2013). Evaluation and Social Impact Measurement Amongst Small to Medium Social Enterprises: Process, Purpose and Value. Australian Journal of Public Administration, 72(4), 447-458. https://doi.org/10.1111/1467-8500.12042

Baumeister, R. F., Vohs, K. D., \& Oettingen, G. (2016). Pragmatic prospection: How and why people think about the future. Review of General Psychology, 20(1), 3-16. https://doi.org/10.1037/gpr0000060

Bayerl, S., Lauche, K., \& Axtell, C. (2016). Revisiting group-based technology adoption as a dynamic process: The role of changing attitude-rationale configurations. Mis Quarterly, 40(3), 775-784. https://doi.org/10.25300/MISQ/2016/40.3.12

Bhattarai, C. R., Kwong, C. C., \& Tasavouri, M. (2019). Market orientation, market disruptiveness capability and social enterprise performance: An empirical study from the United Kingdom. Journal of Business Research, 96, 47-60. https://doi.org/10.1016/j.jbusres.2018.10.042

Block, J. H., Fisch, C. O., \& Van Praag, M. (2018). Quantity and quality of jobs by entrepreneurial firms. Oxford Review of Economic Policy, 34(4), 565-583. https://doi.org/10.1093/oxrep/gry016

Brandt, M. J., \& Wetherell, G. A. (2012). What attitudes are moral? The case of attitude heritability. Social Psychological and Personality Science, 3(2), 172-179. https://doi.org/10.1177/1948550611412793

Brooks, A. C. (2009). Social Entrepreneurship: A Modern Approach to Social Value Creation. Prentice-Hall, Upper Saddle River, NJ.

Bruin, A., Shaw, E., \& Lewis, K. (2017). The collaborative dynamic in social entrepreneurship. Entrepreneurship and Regional Development An International Journal, 29(7-8). https://doi.org/10.1080/08985626.2017.1328902

Cassells, S., \& Lewis, K. (2011). SMEs and Environmental Responsibility: Do Actions Reflect Attitudes? Corporate Social Responsibility and Environmental Management, 18, 186-199. https://doi.org/10.1002/csr.269 


\section{MInstitute ${ }^{\text {Mink }}$}

International Journal of Management Innovation Systems

ISSN 1943-1384

Cristea, M., \& Gheorghiu, A. (2016). Attitude perceived behavioural control, and intention to adopt risky behaviours. Transportation Research Part F: Traffic Psychology and Behaviour, 43, 157-165. https://doi.org/10.1016/j.trf.2016.10.004

Cutchin, M. P., \& Dickie, V. A. (2012). Transactional: Occupational science and the pragmatic Attitude. Critical Perspectives On occupational science: Society, inclusion, participation, 23-37. https://doi.org/10.1002/9781118281581.ch3

Dillenburg, S., Greene, T., \& Erekson, O. H. (2003). Approaching socially responsible investment with a comprehensive rating scheme: Total social impact. Journal of Business Ethics, 43(3), 167-177. https://doi.org/10.1023/A:1022987127960

Dong, B., Xu, H., Luo, J., Nicol, C. D., \& Liu, W. (2020). Many roads lead to Rome: How entrepreneurial orientation and trust boost the positive network range and entrepreneurial performance relationship. Industrial Marketing Management, 88, 173-185. https://doi.org/10.1016/j.indmarman.2020.04.016

Drayton, W. (2002). The Citizen Sector: Becoming an entrepreneurial and competitive business. California Management Review, 44(3), 120-132. https://doi.org/10.2307/41166136

Emerson, J. (2003). The Blended Value Proposition: Integrating Social and Financial Returns. California Management Review, 45(4). https://doi.org/10.2307/41166187

Evans, S., Vladimirova, D., Holgado, M., Van Fossen, K., Yang, M., Silva, E. A., \& Barlow, C. Y. (2017). Business model innovation for sustainability: Towards a unified perspective for the creation of sustainable business models. Business Strategy and the Environment, 26(5), 597-608. https://doi.org/10.1002/bse.1939

Ferri, L., Ginesti, G., Spano, R., \& Zampella, A. (2019). Exploring factors motivating entrepreneurial intentions: The case of Italian university students. International Journal of Training and Development, 23(3), 202-220. https://doi.org/10.1111/ijtd.12158

$\mathrm{Fu}, \mathrm{T}$. (2019). Exploring the effects of norms attributes on daily non-work-related mode choice on Chinese students in the Netherlands (Master's thesis).

Ganesan, K. (n. d.). Employee attitude change in adopting a market orientation and integrated e-CRM in large corporations in SA (Doctoral dissertation).

Grover, V., \& Kohli, R. (2013). Revealing your hand: Caveats in implementing digital business strategy. Mis Quarterly, 655-662.

Gull, S., Hanchinal, A., \& Salma, M. B. (2013). Social Accounting - A survey. International Journal of Application or Innovation in Engineering \& Management (IJAIEM). https://www.ijaiem.org/Volume2Issue5/IJAIEM-2013-05-30-084.pdf

Hagger, M. S. (2019). The reasoned action approach and the theories of reasoned action and planned behaviour. https://doi.org/10.1093/obo/9780199828340-0240

Hahn, R., \& Kühnen, M. (2013). Determinants of Sustainability Reporting: A Review of Results, Trends, Theory, and Opportunities in an Expanding Field of Research. Journal of 
Cleaner Production, 59, 5-21. https://doi.org/10.1016/j.jclepro.2013.07.005

Ham, M., Jeger, M., \& FrajmanIvković, A. (2015). The role of subjective norms in forming the intention to purchase green food. Economic research-Ekonomskaistraživanja, 28(1), 738-748. https://doi.org/10.1080/1331677X.2015.1083875

Han, H., Meng, B., \& Kim, W. (2017). Emerging bicycle tourism and the theory of planned behaviour. Journal of Sustainable Tourism, 25(2), 292-309. https://doi.org/10.1080/09669582.2016.1202955

Hardin-Fanning, F., \& Ricks, J. M. (2017). Attitudes, social norms and perceived behavioural control factors influencing participation in a cooking skills program in rural Central Appalachia. Global health promotion, 24(4), 43-52. https://doi.org/10.1177/1757975916636792

Harmon-Jones, E. E. (2019). Cognitive dissonance: Reexamining a pivotal theory in psychology (pp. xvi-303). American Psychological Association. https://doi.org/10.1037/0000135-000

Hertzberg, J., Rask, L., \& Bengtsson, S. (2020). The relationship between service quality, customer satisfaction and brand loyalty: A study comparing generation X and Y in Sweden.

Hilton, J. (2017). Growth patterns and emerging opportunities in nutraceutical and functional food categories: a market overview. Developing new functional food and nutraceutical products (pp. 1-28). Academic Press. https://doi.org/10.1016/B978-0-12-802780-6.00001-8

Honnacker, A. (2018). Approaching Pragmatic Humanism. In Pragmatic Humanism Revisited (pp. 7-17). Palgrave Pivot, Cham. https://doi.org/10.1007/978-3-030-02441-3_2

Huhtala, M., Lämsä, A. M., \& Feldt, T. (2019). Applying the identity status paradigm to managers' moral identity. Scandinavian Journal of Work and Organisational Psychology, 4(1). https://doi.org/10.16993/sjwop.50

Jamali, D., \& Karam, C. (2018). Corporate social responsibility in developing countries as an emerging field of study. International Journal of Management Reviews, 20(1), 32-61. https://doi.org/10.1111/ijmr.12112

Judge, T. A., Weiss, H. M., Kammeyer-Mueller, J. D., \& Hulin, C. L. (2017). Job attitudes, job satisfaction, and job affect: A century of continuity and change. Journal of Applied Psychology, 102(3), 356. https://doi.org/10.1037/ap10000181

Kania, J., \& Kramer, M. R. (2011). Collective Impact. Stanford Social Innovation Review, Winter, 36-41.

Kania, J., \& Kramer, M. R. (2013). Embracing Emergence: How Collective Impact Addresses Complexity. Stanford Social Innovation Review, January, 1-7.

Kaushik, V., \& Walsh, C. A. (2019). Pragmatism as a research paradigm and its implications for social work research. Social Sciences, 8(9), 255. https://doi.org/10.3390/socsci8090255 


\section{Mll Macrothink}

International Journal of Management Innovation Systems

ISSN 1943-1384

2021, Vol. 6, No. 1

Killian, S., \& O'Regan, P. (2016). Social accounting and the co-creation of corporate legitimacy. Accounting, Organisations and Society, 50, 1-12. https://doi.org/10.1016/j.aos.2016.02.004

Kiriakidis, S. (2017). Perceived behavioural control in the theory of planned behaviour: Variability of conceptualisation and operationalisation and implications for measurement. In Strategic Innovative Marketing (pp. 197-202). Springer, Cham. https://doi.org/10.1007/978-3-319-33865-1_25

Kocollari, U., \& Lugli, E. (2020). Social Accounting at Work: An Analysis of Social Impact Measurement Models.

Koli, L. N., \& Rawat, B. (2012). Corporate Social Reporting Practices in Global Scenario - A Case Study of Hero Honda. BVIMR Management Edge, 5(2), 29-34.

Krueger, N. (2005). The cognitive psychology of entrepreneurship. In Z. Acs, \& D. Audretsch (Eds.), Handbook of entrepreneurship research (pp. 105-140). https://doi.org/10.1007/0-387-24519-7_6

Lavergne, K. J., \& Pelletier, L. G. (2016). Why is attitude-behaviour inconsistencies uncomfortable? Using motivational theories to explore individual differences in dissonance arousal and motivation to compensate. Motivation and Emotion, 40(6), 842-861. https://doi.org/10.1007/s11031-016-9577-3

Lee, S. H., \& Ha-Brookshire, J. E. (2020). In pursuit of corporate sustainability: factors contributing to employees' workplace behaviour. Journal of Fashion Marketing and Management: An International Journal. https://doi.org/10.1108/JFMM-09-2019-0203

Lencioni, P. (2002). Teamwork in non-profits: 5 Dysfunctions of a Team Model.

Lingane, A., \& Olsen, S. (2004). Guidelines for Social Return On Investment. California Management Review, 46(3). https://doi.org/10.2307/41166224

Linnenluecke, M. K., \& McKnight, B. (2017). Community resilience to natural disasters: the role of disaster entrepreneurship. Journal of Enterprising Communities: People and Places in the Global Economy. https://doi.org/10.1108/JEC-01-2015-0005

Liu, M. T., Liu, Y., \& Mo, Z. (2020). Moral norm is the key. Asia Pacific Journal of Marketing and Logistics. https://doi.org/10.1108/APJML-05-2019-0285

Long, T. B., Iñigo, E., \& Blok, V. (2020). Responsible management of innovation in business. In Research Handbook of Responsible Management. Edward Elgar Publishing. https://doi.org/10.4337/9781788971966.00051

Luttrell, A., Petty, R. E., Briñol, P., \& Wagner, B. C. (2016). Making it moral: Merely labeling an attitude as moral increases its strength. Journal of Experimental Social Psychology, 65, 82-93. https://doi.org/10.1016/j.jesp.2016.04.003

Mair, J., \& Marti, I. (2005). Social entrepreneurship research: A source of explanation, prediction and delight. IISE Business School-University of Navarra, March 2004. 
https://doi.org/10.2139/ssrn.673446

Mair, J., \& Martí, I. (2006). Social entrepreneurship research: A source of explanation, prediction, and delight. Journal of World Business, 41, 36-44. https://doi.org/10.1016/j.jwb.2005.09.002

Mair, J., \& Noboa, E. (2006). Social entrepreneurship: How intentions to create a social venture is formed. Social entrepreneurship (pp. 121-135). New York: Palgrave Macmillan. https://doi.org/10.1057/9780230625655_8

Martela, F. (2015). Pragmatism as an attitude. Action, belief and inquiry-Pragmatist perspectives on science, society and religion, 187-207.

Martin, R., \& Osberg, S. (2007). Social entrepreneurship: the case for definition. Stanford Social Innovation Review, 5(3), 28-39.

Mastrangelo, L. M., Benitez, D. G., \&Cruz-Ros, S. (2017). How Social Entrepreneurs can Influence their Employees' Commitment. Journal of Promotion Management, 23(3), 437-448. https://doi.org/10.1080/10496491.2017.1294878

McConachie, J., \& Simpson, J. (2003). Social entrepreneurship: An Australian university transform a regional community through diversity and innovation. Queensland Journal of Educational Research, 19(2), 100-118.

Molecke, G., \& Pinkse, J. (2017). Accountability for social impact: A bricolage perspective on impact measurement in social enterprises. Journal of Business Venturing, 32(5), 550-568. https://doi.org/10.1016/j.jbusvent.2017.05.003

Morse, R. S., \& Dudley, L. (2002). Civic entrepreneurs and collaborative leadership. PATimes, 25(8), 3 .

Newspaper, F. (2013, September 16). Lack of CSR practices in Pakistan. Retrieved from https://www.dawn.com/news/1043179

Nga, J. K. H., \& Shamuganathan, G. (2010). The influence of personality traits and demographic factors on social entrepreneurship start-up intentions. Journal of Business Ethics, 95(2), 259-282. https://doi.org/10.1007/s10551-009-0358-8

Nicholls, A., \& Cho, A. H. (2008). Social entrepreneurship: the structuration of a field", in Nicholls, A. (Ed.), Social Entrepreneurship: New Models of Sustainable Social Change (pp. 44-55). Oxford University Press, New York, NY.

Nolan, J., \& Frishling, N. (2020). Human rights due diligence and the (over) reliance on social auditing in supply chains. In Research Handbook on Human Rights and Business. Edward Elgar Publishing. https://doi.org/10.4337/9781786436405.00012

Norasmah, O., \& Hariyaty, A. W. (2014). Social Entrepreneurship among participants in the students in free enterprise program. Education + Training, 56(8/9), 852-869. https://doi.org/10.1108/ET-09-2013-0111 


\section{$\Lambda$ Macrothink}

International Journal of Management Innovation Systems ISSN 1943-1384

Nsereko et al. (2017). Personal initiative: Its power in social entrepreneurial venture creation. Cogent Business \& Management, 5(1). https://doi.org/10.1080/23311975.2018.1443686

Othman, N., \& Wahid, H. A. (2014). Social Entrepreneurship among Participants in the Students in Free Enterprise Program. https://doi.org/10.1108/ET-09-2013-0111

Pedersen, E. R. G., Neergaard, P., Pedersen, J. T., \& Gwozdz, W. (2013). Conformance And Deviance: Company Responses To Institutional Pressures For Corporate Social Responsibility Reporting. Business Strategy and the Environment, 22, 357-373. https://doi.org/10.1002/bse.1743

Peifer, J. L., Johnson, D. R., \& Ecklund, E. H. (2020). Is the Market Perceived to be Civilizing or Destructive? Scientists' Universalism Values and Their Attitudes Towards Patents. Journal of Business Ethics, 1-15. https://doi.org/10.1007/s10551-020-04633-y

Pejic, B. M., Aleksic, A., \& Merkac-Skok, M. (2018). Examining determinants of entrepreneurial intentions in Slovenia: Applying the theory of planned behaviour and an innovative cognitive style. Economic research-Ekonomskaistraživanja, 31(1), 1453-1471. https://doi.org/10.1080/1331677X.2018.1478321

Phills, J. Jr., Deiglmeier, K., \& Miller, D. (2008). Rediscovering social innovation. Stanford Social Innovation Review, 6(4), 34-43.

Porter, M., \& Kramer, M. R. (2011). Creating Shared Value. Harvard Business Reviews.

Pyka, A. (2017). Dedicated innovation systems to support the transformation towards sustainability: Creating income opportunities and employment in the knowledge-based digital bioeconomy. Journal of Open Innovation: Technology, Market, and Complexity, 3(4), 27. https://doi.org/10.1186/s40852-017-0079-7

Qin, X., Huang, M., Hu, Q., Schminke, M., \& Ju, D. (2018). Ethical leadership, but toward whom? How moral identity congruence shapes the ethical treatment of employees. Human Relations, 71(8), 1120-1149. https://doi.org/10.1177/0018726717734905

Rauch, A., \& Frese, M. (2007). Born to be an entrepreneur? Revisiting the personality approach to entrepreneurship. In J. B. Baum, M. Frese, \& R. A. Baron (Eds.), The Psychology of Entrepreneurship. Lawrence Erlbaum Associates, London.

Reynolds, J. M. (2004). "Pragmatic Humanism” in Foucault's Later Work. Canadian Journal of Political Science/Revue canadienne de science politique, 37(4), 951-977. https://doi.org/10.1017/S000842390499018X

Rezaei, R., Safa, L., Damalas, C. A., \&Ganjkhanloo, M. M. (2019). Drivers of farmers' intention to use integrated pest management: Integrating the theory of planned behaviour and norm activation model. Journal of environmental management, 236, 328-339. https://doi.org/10.1016/j.jenvman.2019.01.097

Robinson, J. (Ed.). (2006). Navigating social and institutional barriers to markets: How social entrepreneurs identify and evaluate opportunities. New York: Palgrave Macmillan. 
https://doi.org/10.1057/9780230625655_7

Röttger, S., Maier, J., Krex-Brinkmann, L., Kowalski, J. T., Krick, A., Felfe, J., \& Stein, M. (2017). Social cognitive aspects of the participation in workplace health promotion as revealed by the theory of planned behaviour. Preventive medicine, 105, 104-108. https://doi.org/10.1016/j.ypmed.2017.09.004

Schunk, D. H., \& DiBenedetto, M. K. (2020). Motivation and social cognitive theory. $\begin{array}{llll}\text { Contemporary } \quad \text { Educational } & \text { Psychology, } & 601832 .\end{array}$ https://doi.org/10.1016/j.cedpsych.2019.101832

Sciencedirect.com. (2016). Theory of Reasoned Action - an overview. Retrieved from https://www.sciencedirect.com/topics/medicine-and-dentistry/theory-of-reasoned-action.

See Change. (2017). How to Build Effective Teams for Social Impact: In Convo with the founder of Shifting Patterns Consulting. The Magazine of Social Entrepreneurship. https://www.seechangemagazine.com/?p=4449

Seelos, C., \& Mair, J. (2004). Social Entrepreneurship: the Contribution of Individual Entrepreneurs to Sustainable Development. AnselmoRubitralta Center for Globalisation and Strategy Center for Business in Society. The University of Navarra. Working Paper. WP No. 553. https://doi.org/10.2139/ssrn.701181

Shane, S., \& Venkataraman, S. (2007). The promise of entrepreneurship as a field of research. The Academy of Management Review, 25(1), 217-226. https://doi.org/10.5465/amr.2000.2791611

Sharir, M., \& Lerner, M. (2006). Gauging the success of social ventures initiated by individual social entrepreneurs. Journal of World Business, 41(1), 6-20. https://doi.org/10.1016/j.jwb.2005.09.004

Shin, Y. H., \& Hancer, M. (2016). The role of attitude, subjective norm, perceived behavioural control, and moral norm in the intention to purchase local food products. Journal of foodservice business research, 19(4), 338-351. https://doi.org/10.1080/15378020.2016.1181506

Siciliano, M. D., Moolenaar, N. M., Daly, A. J., \&Liou, Y. H. (2017). A cognitive perspective on policy implementation: reform beliefs, sensemaking, and social networks. Public Administration Review, 77(6), 889-901. https://doi.org/10.1111/puar.12797

Smith, R. A., Kim, Y., Zhu, X., Doudou, D. T., Sternberg, E. D., \& Thomas, M. B. (2018). Integrating models of diffusion and behaviour to predict innovation adoption, maintenance, and social diffusion. Journal of health communication, 23(3), 264-271. https://doi.org/10.1080/10810730.2018.1434259

Smorodinskaya, N., Russell, M., Katukov, D., \& Still, K. (2017, January). Innovation ecosystems vs. innovation systems in terms of collaboration and co-creation of value. In Proceedings of the 50th Hawaii international conference on system sciences. https://doi.org/10.24251/HICSS.2017.636 


\section{MInstitute Macrothink $^{\text {Int }}$}

International Journal of Management Innovation Systems ISSN 1943-1384

Source for case study martin dow 2020. Merck returning the land's promise 1st Edition; "survey"; "Direct and indirect Interviews" from Mr Muhammad Owais (procurement officer), MrSaqib (supply chain and CSR initiator), Mr Burhan Khan (Finance officer).

Spek, T., Schreven, A., \& Velden, F. (2014). The three roles of social business leadership. The Broker: Connecting Worlds of Knowledge.http://www.thebrokeronline.eu/Blogs/Social-Entrepreneurship/The-three-roles-ofsocial-business-leadership

Stevenson, A., \& Sundberg, J. (2014). The legitimacy of social accounting: A case study of SME managers'attitudes and actions. Uppsala University.

Sultanova, G. S. (2020). SCIENTIFIC THINKING: INNOVATION AND INNOVATION ACTIVITIES. Современнаянаука: новыеподходы и актуальныеисследования, 170-173.

Svasta, M. (2017, October). Integrated Model of Innovation-a pragmatic and structured approach of innovation. In International Conference on Management and Industrial Engineering (No. 8, pp. 112-119). Niculescu Publishing House.

Tasselli, S., Kilduff, M., \& Landis, B. (2018). Personality change: Implications for organisational behaviour. Academy of Management Annals, 12(2), 467-493. https://doi.org/10.5465/annals.2016.0008

Thi, X. M. H., \& Ottar, O. S. (2016). Consumer participation in self-production: The role of control mechanisms, convenience orientation, and moral obligation. Journal of Marketing Theory and Practice, 24(2), 209-223. https://doi.org/10.1080/10696679.2016.1130554

Thomas, T. E., \& Lamm, E. (2012). Legitimacy and Organisational Sustainability. Journal of Business Ethics, 100, 191-203. https://doi.org/10.1007/s10551-012-1421-4

Thompson, J. L., Alvy, G., \& Lees, A. (2000). Social entrepreneurship - a new look at the people and the potential. Management Decision, 38(5), 328-338. https://doi.org/10.1108/00251740010340517

Tims, M., \& Bakker, A. B. (2010). Job crafting: Towards a new model of individual job $\begin{array}{lllll}\text { redesign. } \quad S A \text { Journal of Industrial Psychology, } 36(2), & 1-9 .\end{array}$ https://doi.org/10.4102/sajip.v36i2.841

Todres and Lewis. (2012). Why social entrepreneurship matters. Enterprising Matters Magazine, summer 2012. Retrieved September 20, 2013, from http://www.isbe.org.uk/Why-SocialEntrepreneurship-Matters

Tomasello, M. (2020). The role of roles in uniquely human cognition and sociality. Journal for the Theory of Social Behaviour, 50(1), 2-19. https://doi.org/10.1111/jtsb.12223

Torrecchia P. (2013) Social Accounting. In S. O. Idowu, N. Capaldi, L. Zu, A. D. Gupta (Eds.), Encyclopedia of Corporate Social Responsibility. Springer, Berlin, Heidelberg. https://doi.org/10.1007/978-3-642-28036-8_191

Turner, D., \& Martin, S. (2005). Social entrepreneurship and social inclusion: building local 


\section{I Macrothink}

International Journal of Management Innovation Systems

ISSN 1943-1384

capacity or delivering national priorities. International Journal of Public Administration, 28(9/10), 797-806. https://doi.org/10.1081/PAD-200067342

Usai, A., Scuotto, V., Murray, A., Fiano, F., \& Dezi, L. (2018). Do entrepreneurial knowledge and innovative attitude overcome "imperfections" in the innovation process? Insights from SMEs in the UK and Italy. Journal of Knowledge Management. https://doi.org/10.1108/JKM-01-2018-0035

Verčič, A. T., \& Ćorić, D. S. (2018). The relationship between reputation, employer branding and corporate social responsibility. Public Relations Review, 44(4), 444-452. https://doi.org/10.1016/j.pubrev.2018.06.005

Verma, A. (2009). Social Entrepreneurship Management - A New Look at the People and the Potential. Global India Publications Pvt Ltd, New Delhi.

Watts, L. L., Steele, L. M., \& Mumford, M. D. (2019). Making sense of pragmatic and charismatic leadership stories: Effects on vision formation. The Leadership Quarterly, 30(2), 243-259. https://doi.org/10.1016/j.leaqua.2018.09.003

Yadav, L. (n. d.). Impact of Cognitive Dissonance.

Yang, C. M. (2018). Effects of Message Strategy and Need for Cognition (NFC) on Consumer Attitudes: A Case of Corporate Social Responsibility (CSR) Advertising. Open $\begin{array}{llll}\text { Journal of Business } \text { and } & \text { 714-732. }\end{array}$ https://doi.org/10.4236/ojbm.2018.63055

Yang, Z., Deng, L. J., \& Fang, E. (2010). Market orientation, strategic flexibility and performance: The moderating effect of environmental uncertainty. China Soft Science, 46(9), 130-139.

Yuen, T. (2011). Unleashing social innovation for the social economy: an experience of social enterprise development in Hong Kong. China Journal of Social Works. https://doi.org/10.1080/17525098.2011.618446

Yunis, M. S., Durrani, L., \& Khan, A. (2017). Corporate social responsibility (CSR) in Pakistan: A critique of the literature and future research agenda. Business \& Economic Review, 9(1), 65-88. https://doi.org/10.22547/BER/9.1.4

\section{Copyright Disclaimer}

Copyright for this article is retained by the author(s), with first publication rights granted to the journal.

This is an open-access article distributed under the terms and conditions of the Creative Commons Attribution license (http://creativecommons.org/licenses/by/3.0/). 